Prepared in cooperation with the U.S. Environmental Protection Agency, Office of Research and Development

\title{
Hydrologic Characteristics of Low-Impact Stormwater Control Measures at Two Sites in Northeastern Ohio, 2008-13
}
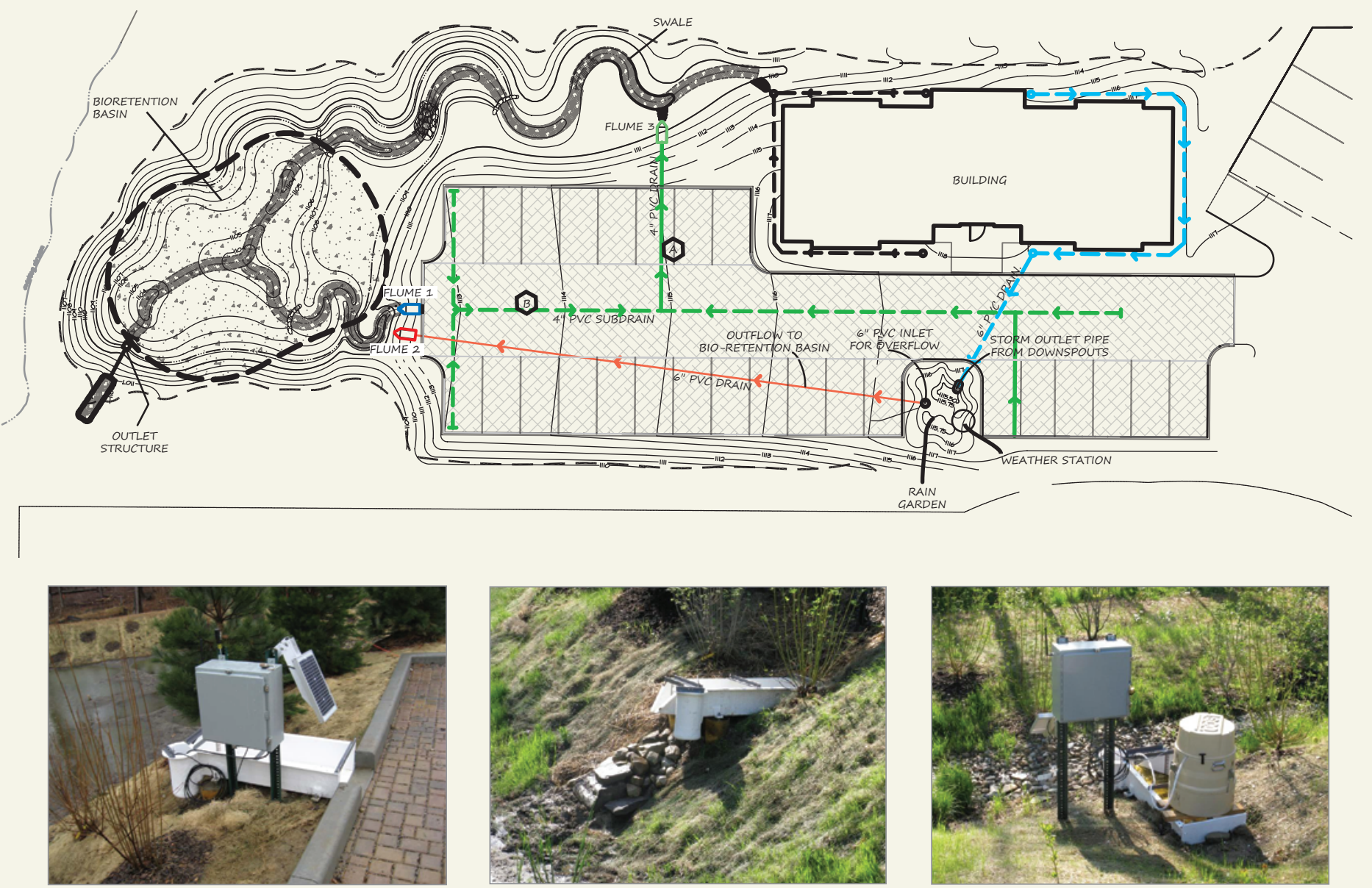

Scientific Investigations Report 2015-5030 
Cover. Schematic site plan for stormwater best-management practices at the Washington Street site, Geauga County, Ohio (top), and photos of three flumes (bottom, left to right). Flume 1 measures surface flow over the parking lot, flume 2 measures any overflow from the rain garden, flume 3 measures the flow from the drain line. 


\section{Hydrologic Characteristics of Low-Impact Stormwater Control Measures at Two Sites in Northeastern Ohio, 2008-13}

By Robert A. Darner, William D. Shuster, and Denise H. Dumouchelle

Prepared in cooperation with the U.S. Environmental Protection Agency, Office of Research and Development

Scientific Investigations Report 2015-5030 


\title{
U.S. Department of the Interior SALLY JEWELL, Secretary
}

\section{U.S. Geological Survey Suzette M. Kimball, Acting Director}

\author{
U.S. Geological Survey, Reston, Virginia: 2015
}

For more information on the USGS - the Federal source for science about the Earth, its natural and living resources, natural hazards, and the environment—visit http://www.usgs.gov or call 1-888-ASK-USGS.

For an overview of USGS information products, including maps, imagery, and publications, visit http://www.usgs.gov/pubprod/.

Any use of trade, firm, or product names is for descriptive purposes only and does not imply endorsement by the U.S. Government.

Although this information product, for the most part, is in the public domain, it also may contain copyrighted materials as noted in the text. Permission to reproduce copyrighted items must be secured from the copyright owner.

Suggested citation:

Darner, R.A., Shuster, W.D., and Dumouchelle, D.H., 2015, Hydrologic characteristics of low-impact stormwater control measures at two sites in northeastern Ohio, 2008-13: U.S. Geological Survey Scientific Investigations Report 2015-5030, 27 p., http://dx.doi.org/10.3133/sir20155030.

ISSN 2328-0328 (online) 


\section{Contents}

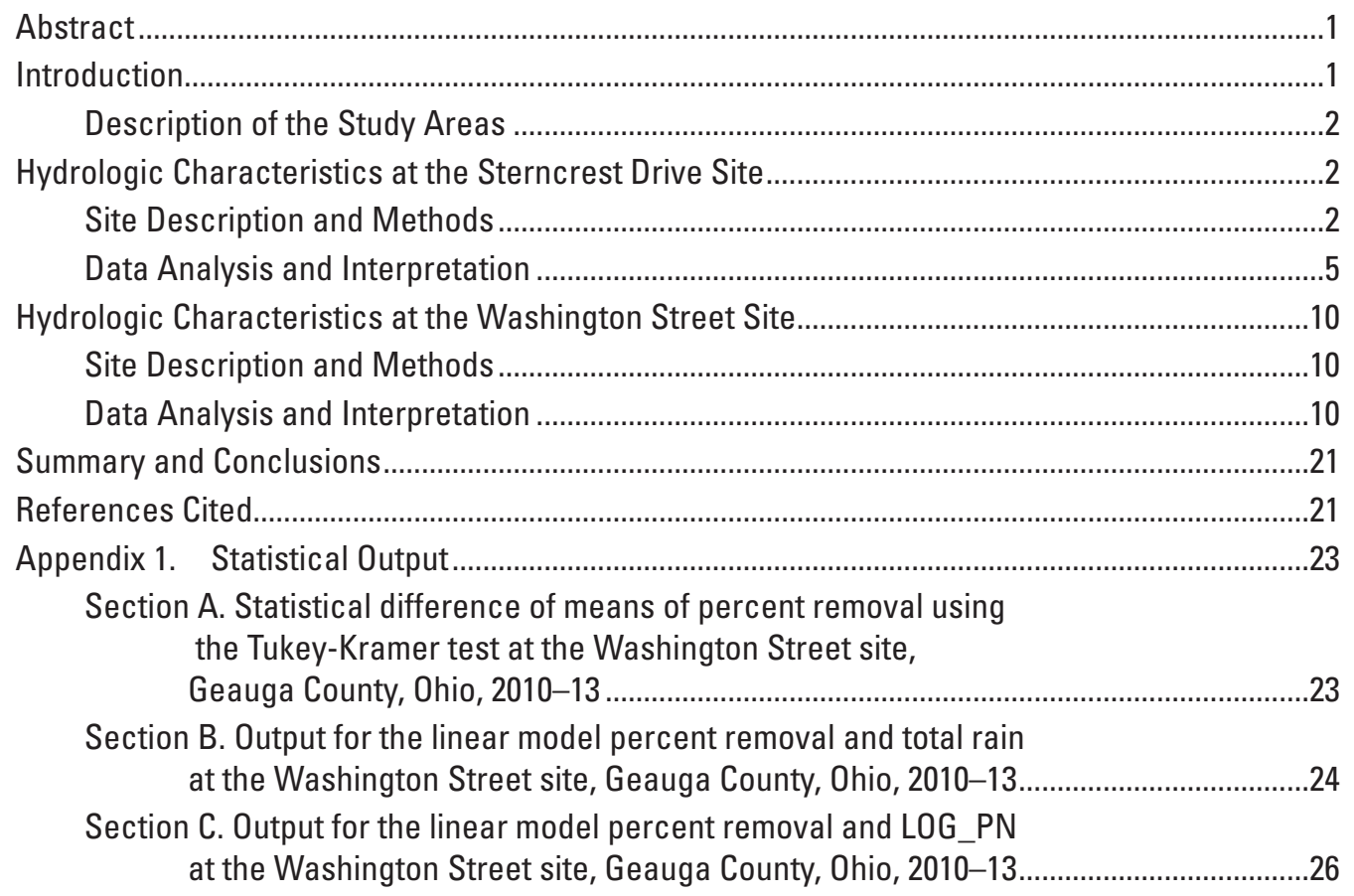

\section{Figures}

1. Map showing location of study area..................................................................................

2. Schematic site plan for the stormwater-control measure along the Sterncrest Drive site, Cuyahoga County, Ohio .....................................................................................

3. Graph showing cumulative overflow indicator and cumulative rain from April 1 to October 31 of each year at the Sterncrest Drive SR1 site, Cuyahoga County, Ohio ...............................................................................................

4. Schematic site plan for stormwater best-management practices at the Washington Street site, Geauga County, Ohio...............................................................11

5. Photographs showing three flumes at the Washington Street site, Geauga County, Ohio

6. Boxplot showing percent removal and bar graph showing the depth of rain starting April 1 and ending October 31, by year, at the Washington Street site, Geauga County, Ohio

7. Boxplots showing climatological and flow characteristics, Washington Street site, Geauga County, Ohio, 2010-13

8. Scatter plots and fit linear least-squares lines for 2010-13, Washington Street site, Geauga County, Ohio .

9. Boxplot showing the percent removal residuals, by year, at the Washington Street site, Geauga County, Ohio.

10. Boxplots showing baseline moisture in soil-moisture sensors, Washington Street site, Geauga County, Ohio, 2010-13. 


\section{Figures-continued}

11. Boxplots showing precipitation-runoff centroid lag times for the Washington Street site, Geauga County, Ohio, 2010-13..............................................................19

12. Graph showing total flow through flumes 2 and 3 for April-0ctober 2010-13 at the Washington Street site, Geauga County, Ohio

\section{Tables}

1. Rain garden overflow time, duration, and precipitation-event depths, Sterncrest Drive SR1 site, Cuyahoga County, Ohio, 2008-13...

2. Rain garden overflow time, duration, and precipitation-event depths, Sterncrest Drive SR2 site, Cuyahoga County, Ohio, 2008-12...

3. Percentage of 0.75 inch or greater rain events that caused an overflow at SR1 with respect to event duration, Sterncrest Drive site, Cuyahoga County, Ohio.

4. Spearman correlations of percent removal to measure antecedent conditions and rain intensity for events with total rainfall greater than or equal to 0.2 inches at the Washington Street site, Geauga County, Ohio 


\section{Conversion Factors}

\begin{tabular}{lcl}
\hline \multicolumn{1}{c}{ Multiply } & By & \multicolumn{1}{c}{ To obtain } \\
\hline inch (in.) & Length & \\
inch (in.) & 2.54 & centimeter $(\mathrm{cm})$ \\
foot (ft) & 25.4 & millimeter $(\mathrm{mm})$ \\
\hline & 0.3048 & meter $(\mathrm{m})$ \\
\hline square mile $\left(\mathrm{mi}^{2}\right)$ & Area & \\
\hline & 2.590 & square kilometer $\left(\mathrm{km}^{2}\right)$ \\
\hline inch per hour $(\mathrm{in} / \mathrm{h})$ & Flow rate & \\
cubic foot per second $\left(\mathrm{ft}^{3} / \mathrm{s}\right)$ & 2.54 & centimeter per hour $(\mathrm{m} / \mathrm{h})$ \\
& 0.02832 & cubic meter per second $\left(\mathrm{m}^{3} / \mathrm{s}\right)$ \\
\hline
\end{tabular}

\section{Datum}

Horizontal coordinate information is referenced to the North American Datum of 1983 (NAD 83).

\section{Abbreviations}

$\begin{array}{ll}\text { BMPS } & \text { best-management practices } \\ \text { CRWP } & \text { Chagrin River Watershed Partners } \\ \text { CSO } & \text { combined sewer overflow } \\ \text { CSS } & \text { combined sewer systems } \\ \text { EPA } & \text { U.S. Environmental Protection Agency } \\ \text { EPA-ORD } & \text { U.S. Environmental Protection Agency-Office of Research and Development } \\ \text { ET } & \text { evapotranspiration } \\ \text { GI } & \text { green infrastructure } \\ \text { LID } & \text { low impact development } \\ \text { MLR } & \text { multiple linear regression } \\ \text { RR } & \text { runoff ratio } \\ \text { SCM } & \text { stormwater-control measure } \\ \text { TDR } & \text { time-domain reflectometer } \\ \text { USGS } & \text { U.S. Geological Survey }\end{array}$





\title{
Hydrologic Characteristics of Low-Impact Stormwater Control Measures at Two Sites in Northeastern Ohio, 2008-13
}

\author{
By Robert A. Darner, ${ }^{1}$ William D. Shuster, ${ }^{2}$ and Denise H. Dumouchelle ${ }^{1}$
}

\section{Abstract}

This report updates and examines hydrologic data gathered to characterize the performance of two stormwatercontrol measure (SCM) sites in the Chagrin River watershed, Ohio. At the Sterncrest Drive site, roadside bioswales and rain gardens were used to alleviate drainage problems in this residential neighborhood area. At the Washington Street site, a treatment train (including a pervious-paver system, rain garden, and bioswales) was used to reduce and delay stormwater runoff at a small business development. Selected metrics were used to demonstrate SCM system performance with regard to stormwater-management objectives at each site. Rain-garden overflow-frequency data collected at the Sterncrest Drive site during 2008-13 were used to characterize system sensitivity to rainfall characteristics. Approximately 70 percent of storms exceeding 0.75 inches during 3 hours or more resulted in overflows. Drainage-design features that may restrict flow through the system were identified. Overall, the data and local observations confirmed the continued success of the SCM at the Sterncrest Drive site in preventing roadway closure due to flooding. The additional years of data collected at the Washington Street site indicated that a previous analysis of increased runoff removal, based on only the first 2 years (2009-10) of data, provided premature conclusions. With 5 years of data (2009-13) and adjusting for changes in rainfall characteristics, it appears that the percentage of runoff removed by the system is decreasing; however, the lag time (time from onset of rainfall to runoff) has remained nearly constant. The annual mean percent removal for 2010-13 ranged from 55 to 37 percent with an overall mean of 45 percent, and this does meet the project objective of reducing runoff from the business complex. One possible explanation for the combination of increased volume of runoff and no change in the timing of runoff is the preferential flow paths developed in the SCM, increasing the capacity for internal drainage. Data indicated that the SCM system at the Washington Street site had reduced functionality over time.

\footnotetext{
${ }^{1}$ U.S. Geological Survey, Ohio Water Science Center.

${ }^{2}$ U.S. Environmental Protection Agency, Office of Research and Development.
}

\section{Introduction}

Stormwater runoff in urban areas is one of the major water-resource management issues in the United States. Impervious surfaces, such as roadways, sidewalks, driveways, and roofs prevent infiltration of rainfall, increasing the volume of runoff from rain events relative to rural areas where more permeable vegetated landscapes have greater infiltration rates. Urban stormwater runoff typically is collected and transferred to a centralized treatment facility with the runoff moving through either separate or combined sewer systems (CSS). In the case of municipal separate storm sewer systems, runoff is routed to a receiving water body like a nearby river or pond. The runoff from the impervious surfaces is often delivered to the receiving water body faster and in greater volume than the surface-water system would naturally receive, which can cause flooding, disturbance to aquatic ecosystems, and increased peak flows in downstream municipalities (Booth and Jackson, 1997). For a CSS, wastewater and stormwater volumes are combined in the same pipe. During some storms, system capacity can be exceeded, and a combined sewer overflow (CSO) occurs, releasing the wastewater-stormwater mixture to the environment.

Low-impact development (LID) and green infrastructure (GI) are best-management practices (BMPs) for managing stormwater volume as near to the source as possible. These decentralized source-control approaches to stormwater management shunt water away from water-treatment plants and involve both structural elements, such as detention basins or rain gardens, and non-structural elements, such as landmanagement education. The LID approach (Dietz, 2007) is a retrofit-oriented management response to excessive urban runoff volume, and is flexible with respect to design so that it can be applied at small scales of development, for example small shopping plazas, residential homes, small businesses, and neighborhoods. GI refers to the concept of linking site design and small-scale stormwater-management objectives across larger spatial scales (for example, municipalities, cities, or regions) by creating connected, contiguous corridors for stormwater detention (Ahern, 2007). BMPs, which may use 
LID designs singly or in combination as a treatment train, include rain gardens, bioswales, pervious-paver systems, rain barrels or cisterns, tree box filters, and curbless roads with swales. LID practices reduce localized runoff, whether through detention, infiltration, or evapotranspiration of stormwater.

Limited data exist on how LID systems perform in practice, and monitoring data are needed to improve the understanding of LID as a stormwater-control measure (SCM). These data may be provided, in part, by targeted research into specific characteristics of SCMs with respect to water-quality benefits and actual reduction in stormwater runoff. Monitoring programs should be conducted for sufficiently long periods of time (for example, 3 to 5 years of typical environmental conditions). The purpose of a monitoring program is to measure the response of LID and GI practices to a broad range of precipitation and climate conditions, and also to understand changes in performance over time. With funding through the U.S. Environmental Protection Agency (EPA) National Community Decentralized Demonstration Project, the Chagrin River Watershed Partners (CRWP) selected four demonstration sites in the Chagrin River watershed to exemplify the process for the design, construction, operation, and monitoring of retrofit LID practices such as SCMs. After the projects had been designed, the EPA-Office of Research and Development (EPA-ORD) collaborated with the U.S. Geological Survey (USGS), Ohio Water Science Center to install and maintain hydrologic monitoring equipment at each of several CRWP projects. These demonstration sites used a range of different BMPs that varied by location as follows:

- A bioswale retrofit to a roadside drainage ditch, Sterncrest Road, Orange Village, Ohio.

- A rain garden and pervious-paver system that drain to a bioretention swale and detention basin to handle stormwater from an expanding small business, Washington Street, Village of South Russell, Ohio.

These projects were selected for long-term monitoring, which involves characterizing the landscape, delineating the drainage area (watershed) at each site, monitoring rainfall inputs, measuring runoff volume through each BMP, and determining water output from the practices as flow into receiving waters. Monitoring of precipitation inputs and runoff volumes was only conducted during the warm season. Darner and Dumouchelle (2011) presented precipitation and runoff data from the sites for 2008-10; in this report, performance characteristics of the BMPs were reexamined using the previously collected data supplemented with an additional 3 years of data collected from 2011 to 2013. Some of the material from Darner and Dumouchelle (2011) is repeated in this report for the reader's convenience. A full discussion of the terms LID, GI, BMP, and SCM can be found in Fletcher and others (2014). For clarity, the treatment practices installed and monitored will be referred to as SCMs in this document.

\section{Description of the Study Areas}

Located east of the Cleveland metroplex, in northeastern Ohio, the Chagrin River watershed drains 265 square miles $\left(\mathrm{mi}^{2}\right)$ of gently rolling hills. The two study sites are near the Chagrin River, where it crosses from Geauga into Cuyahoga County. The Sterncrest Drive site is in Cuyahoga County, near the western boundary of the watershed. The Washington Street site is in western Geauga County, in the upper reaches of the watershed (fig. 1). The area has a humid, temperate climate with average annual precipitation of 47 inches (in.) (Midwestern Regional Climate Center, 2010). Land use is highly variable and includes urban, suburban, rural-residential, forested, and agricultural uses (Jagucki and Darner, 2001). Glacial sediments range from a few feet to around 100 feet (ft) in thickness and overlie sandstone and shale bedrock. Most soils in the watershed are formed in the clay-rich glacial till and are generally classified as silt loams with generally low to very low $(0.6$ to $<0.2$ inches per hour $[\mathrm{in} / \mathrm{h}])$ permeability and high runoff potential. Artificial drainage is suggested for development in this watershed (Musgrave and Holloran, 1980; Williams and McCleary, 1982). The water table at both sites is near the land surface, within 1 to $3 \mathrm{ft}$, particularly in the winter and spring or during unusually wet periods, so the soil has little capacity to store infiltrated water. These soil conditions can lead to flooding; hence, there is a need for adding detention capacity to each of these neighborhood areas by way of retrofitted, short-term detention strategies.

\section{Hydrologic Characteristics at the Sterncrest Drive Site}

The SCM at the Sterncrest Drive site consists of a bioswale retrofit to a roadside drainage ditch with rain gardens. Additional site description and construction details are presented in Darner and Dumouchelle (2011). Precipitation and runoff data were collected at this site from March or April through October 2008-13.

\section{Site Description and Methods}

Near the intersection of Sterncrest Drive and Lander Road, there has been a history of yard and road flooding. In 2007, in an effort to alleviate flooding, about 1,400 linear feet of existing roadside ditches were excavated to a depth of about $5 \mathrm{ft}$. Perforated drain pipe was installed on the north side (8-in. diameter) and south side (15-in. diameter). Bioswales were then created by backfilling the excavation with permeable sediments (sand-compost mixture) and planting grass. The bioswales receive stormwater runoff from the adjacent roadway and overland runoff from the residential area. 


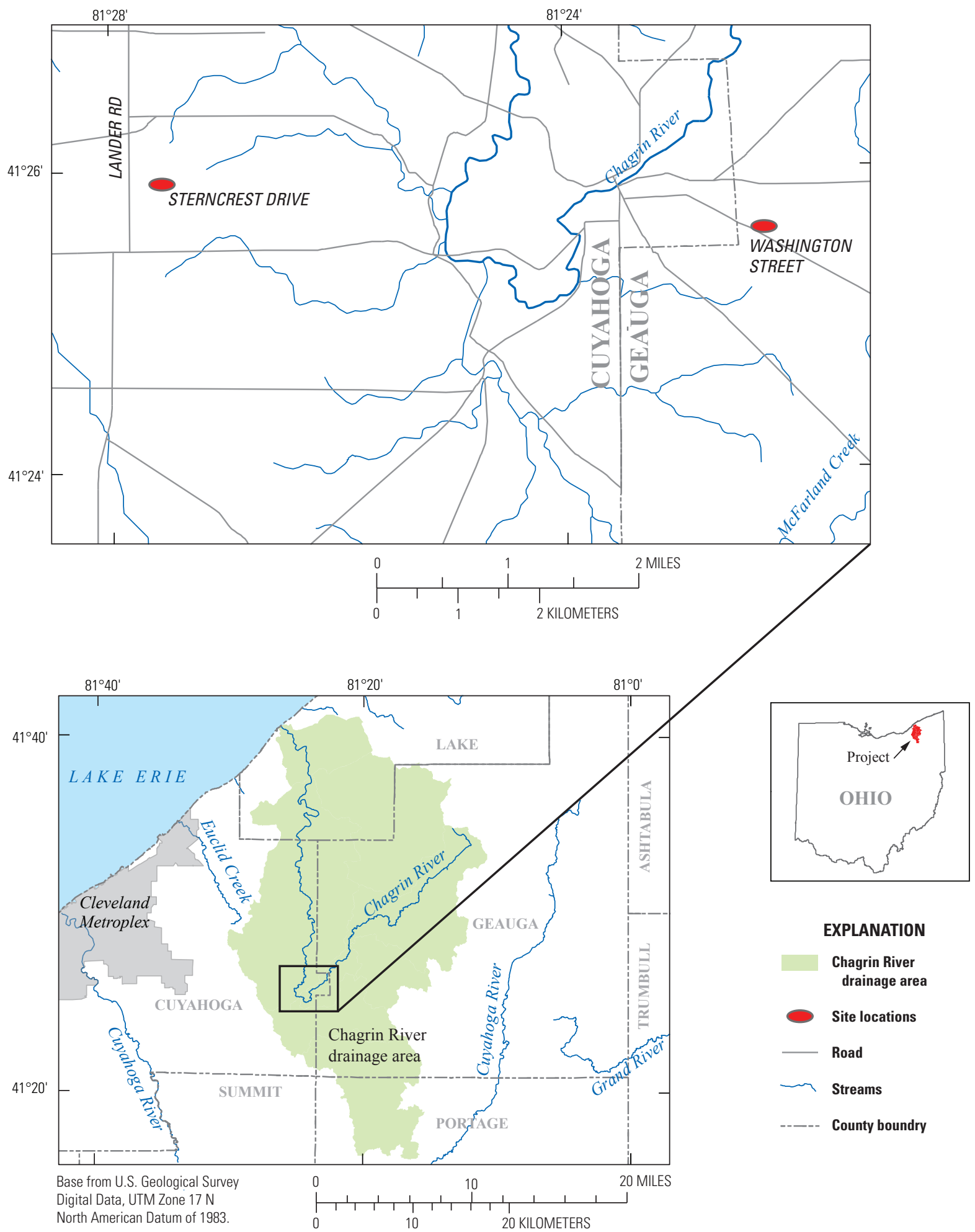

Figure 1. Location of study area. 
A series of rain gardens were installed within the bioswales to increase infiltration and evapotranspiration. A non-perforated storm drain pipe crosses under the road from the north drain pipe to the south drain pipe at each of the paired rain gardens (fig. 2). The rain gardens, which are $4.5 \mathrm{ft}$ wider than the bioswale, were planted with perennial plants and then mulched (Darner and Dumouchelle, 2011). Overflow grates elevated about 6 in. above the mulch prevent excessive ponding in the rain gardens. Water from the buried drains in the bioswale and from the rain-garden-overflow grate discharge to the local stormwater drain.

An unheated tipping-bucket rain gage and an air-temperature sensor were installed behind Orange Village Hall, approximately $1,400 \mathrm{ft}$ west-northwest of the Sterncrest Drive site. The rain gage registered precipitation in $0.01-$ in. increments that were summed by a data logger on a 10-minute interval. Precipitation depths and peak intensities for 10-, 30-, 60-, 120-, and 1,440-minute intervals were determined. Recurrence intervals of precipitation at the site were estimated by using precipitation-frequency tables compiled by the National Oceanic and Atmospheric Administration (Bonnin and others, 2004).
The overflow grates on two rain gardens - one north (SR1) and one south (SR2) of Sterncrest Drive (fig. 2)-were instrumented with sensors that measured specific conductance and temperature. These sensors were used to determine the occurrence and duration of overflows; however, without additional instrumentation, the volume of the overflows could not be computed. The sensors were connected to a data logger adjacent to the rain garden. The data logger queried the sensor every minute and recorded the measurement if there was a change since the last measurement. Data also were recorded every 6 hours to ensure that the data logger was operational during periods when sensor readings were unchanging.

The maximum water levels in the SR1 and SR2 rain gardens were recorded with a crest-stage gage - a simple instrument that records only the highest water elevation, or stage, reached between routine maintenance visits when the gage is reset. The crest-stage reading was compared to the elevation of the overflow grate to verify that overflow did, or did not, occur as indicated by the sensor measurements. In no case was an overflow indicated by a crest-stage gage without an overflow also being indicated by a sensor reading. It cannot be said with certainty whether the reverse was true because more than one overflow may have occurred between inspections of the creststage gage.

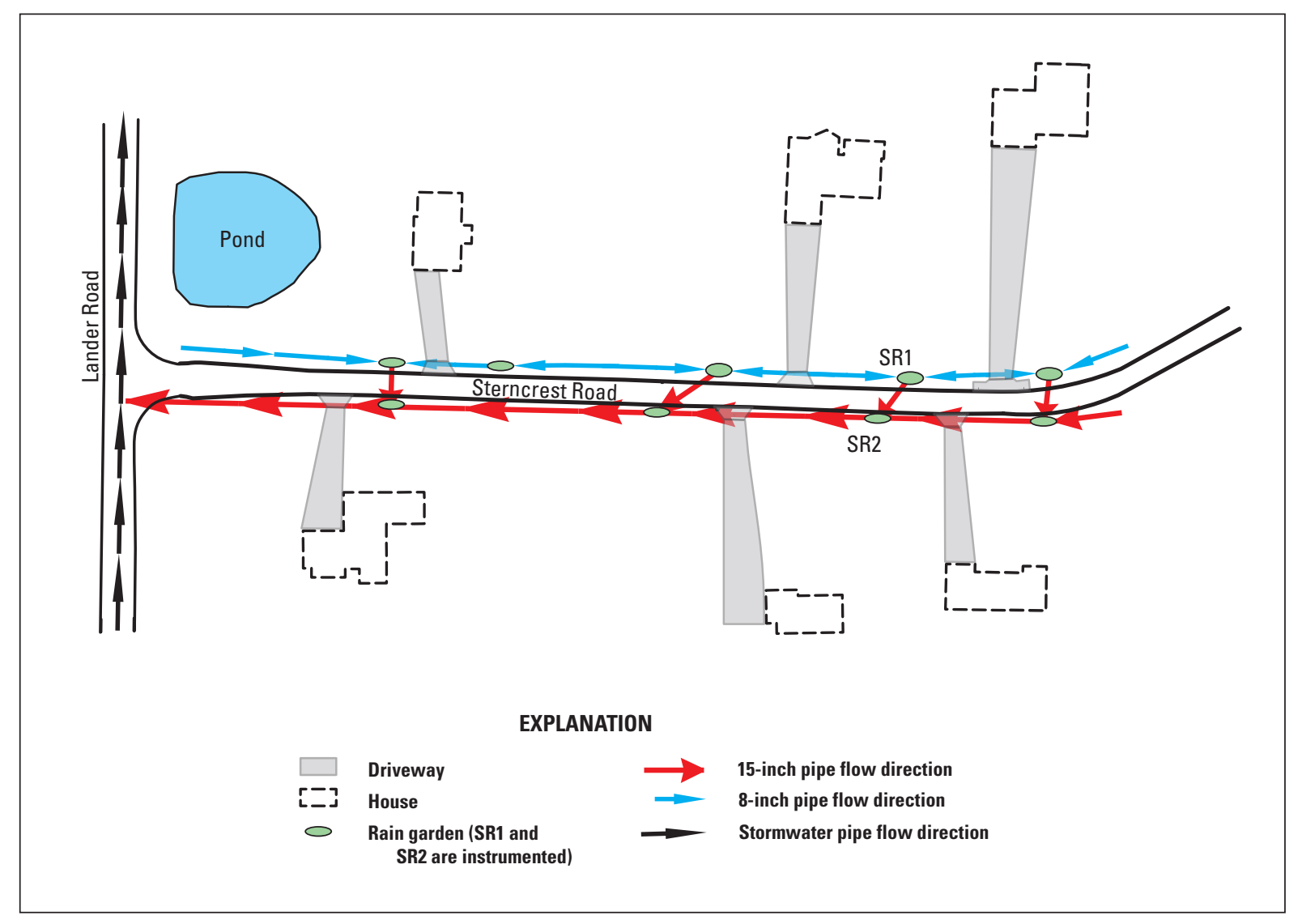

Figure 2. Schematic site plan for the stormwater-control measure along the Sterncrest Drive site, Cuyahoga County, Ohio. 


\section{Data Analysis and Interpretation}

The frequency with which an SCM overflows is one measure of how well the feature functions in response to various rain events and over time. At the Sterncrest Drive site, overflow occurs when the water level in the rain garden rises above the overflow grate, and the overflow volume is shunted directly to the local stormwater system. The design storm for the site was reported to be 0.75 in. of precipitation, but the duration for this rainfall depth was not stated (Brian Mader, Stephen Hovancsek and Associates, Inc., written commun., 2014); therefore, the analysis of data from this site focuses on the frequency of overflows as a function of precipitation amount, with particular emphasis on rain events in excess of 0.75 in.

There were 83 overflows at the SR 1 site from 2008 to 2013: 18 occurred when precipitation in the previous 96 hours did not exceed the 0.75 -in. design storm, and 6 of those had precipitation of at least $0.73 \mathrm{in}$. (table 1). In the 6-year study period, only four overflows at SR1 were associated with a rain event that exceeded the 1-, 2- or 10-year recurrence interval (table 1). During 2008-10, there were 14 overflows at the SR1 site. Additionally, there were 40 overflows in 2011, 11 overflows in 2012, and 18 overflows in 2013.

Only 17 overflows occurred at the SR2 site (table 2) from 2008 to 2012. Six of the overflows occurred with rain totals of less than $0.75 \mathrm{in}$. in the previous 96 hours; however, three of these six overflows occurred on the same day as another event ( 2 and 3; 7 and 8), and the combined rain totals were in excess of $0.75 \mathrm{in}$. In addition, event 16 occurred on the same day as event 60 at SR1 (table 1), which produced 0.88 in. of precipitation. None of the overflow events at SR2 occurred with rain events that exceeded the 1-, 2- or 10-year recurrence interval.

Darner and Dumouchelle (2011) noted that differences in the diameter of drain pipes under each bioswale could be a contributing factor in the greater number of overflows at SR1 as compared to SR2. The north side of the road (SR1) is underlain by an 8-in. drain pipe, which discharges to the 15 -in. pipe on the south side (SR2) of the road, which discharges to the storm sewer (fig. 2). A possible explanation for the difference in the number of overflows at SR1 and SR2 is the smaller conveyance of the 8 -in. pipe versus the 15 -in. pipe and possible backwater in pipes on the south side of the road retarding pipe flow from north to south.

Changes in overflow frequency over time could result from changes in drainage area or rainfall pattern. The drainage area of the SCM could be affected by homeowner landscaping activities that increase the drainage area, or increase the area of impervious surfaces leading to greater runoff. However, conversations with the local residents indicated that they had made no substantial changes to their properties yet they observed more standing water in their yards. In spite of those observations, Sterncrest Drive had not been closed due to flooding, which had occurred frequently before the installation of the bioswale (Matt Scharver, Chagrin River Watershed Partners, written commun., 2012). As the anecdotal information indicated no substantial changes in drainage area or imperviousness, rainfall patterns were investigated to help explain the increase in overflows over time.

Total rainfall measured during April 1-October 31, 2011, was much greater than in other years, which apparently drove the increase in overflow frequency (fig. 3) for that year. The relation between higher-frequency storms with greater overall seasonal depth and overflow status is illustrated in figure 3. If the data from 2011 are excluded (due to the unusual amount of rain), then the number of overflows (even with similar precipitation totals) is increasing year to year (fig. 3).

As noted above, the duration associated with the $0.75 \mathrm{in}$. design storm was not specified. Table 3 lists the percentage of rainfall events that equaled or exceeded a total of $0.75 \mathrm{in}$. for selected durations and resulted in overflows at SR1. Not surprisingly, overflows occur more frequently when $0.75 \mathrm{in}$. or greater of precipitation occurs over a short duration as compared to longer durations. The percentage of overflows associated with equaling or exceeding the $0.75 \mathrm{in}$. design depth appears to plateau at around 70 percent for durations greater than or equal to 3 hours. In other words, about 70 percent of rainfall events that produced at least $0.75 \mathrm{in}$. of rain over 3 hours or more resulted in an overflow at SR1. At SR1, a rainfall of 1.24 in. over 3 hours has a 1-year average recurrence interval (Bonnin and others, 2004); thus, it could be expected that a smaller rainfall-such as $0.75 \mathrm{in}$. in 3 hours - is likely to occur more frequently (averaging more than once per year). Therefore, the Sterncrest Drive SCM can be expected to overflow multiple times a year, a frequency that may be too often for the goals of other SCMs designs. However, this system has met the local objectives of street-level flood control in a residential neighborhood (Matt Scharver, Chagrin River Watershed Partners, written commun., 2012).

As the system continues to age, the number of overflows could increase due, in part, to clogging of bioswale surface soils and of the perforations in the pipes with sediment suspended in inflows, which could decrease infiltration rates. Also, clogging of the subsurface sediments may result in less system-detention capacity. Evidence of clogging could be observed in an uneven pattern in percolation, i.e., ponding in some areas of the bioswale. With either surficial or subsurface clogging, an increase in overflow frequency may then be observed for progressively smaller storms. 
Table 1. Rain garden overflow time, duration, and precipitation-event depths, Sterncrest Drive SR1 site, Cuyahoga County, Ohio, 2008-13.

[The durations of the precipitation depths are based on the start time of the overflow. Red highlight, greater than or equal to the 10-year precipitation event; green highlight, greater than or equal to the 2-year precipitation event; yellow highlight, greater than or equal to the 1-year precipitation event (based on precipitation magnitude and frequency computations by Bonnin and others, 2004)]

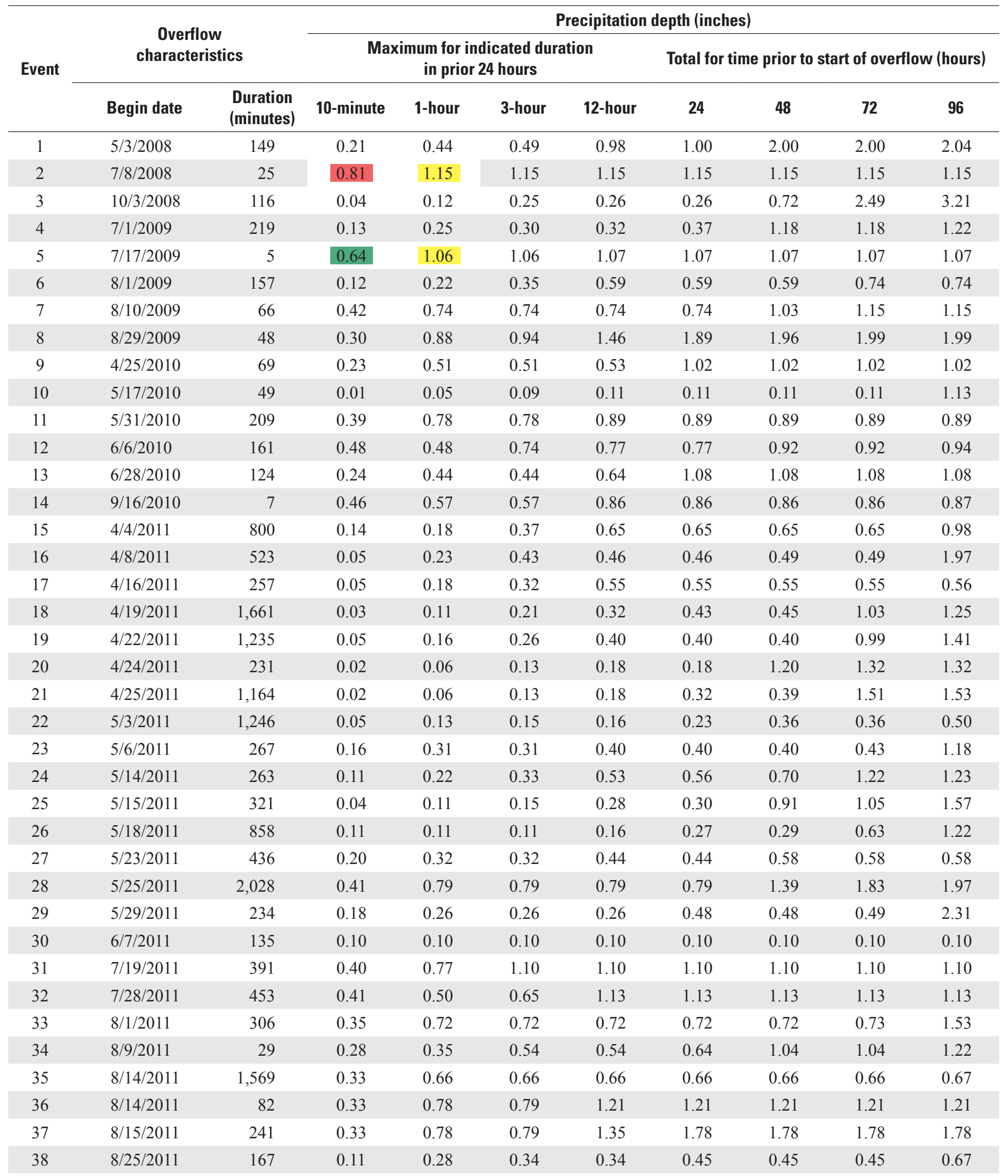


Table 1. Rain garden overflow time, duration, and precipitation-event depths, Sterncrest Drive SR1 site, Cuyahoga County, Ohio, 2008-13.-Continued

[The durations of the precipitation depths are based on the start time of the overflow. Red highlight, greater than or equal to the 10-year precipitation event; green highlight, greater than or equal to the 2-year precipitation event; yellow highlight, greater than or equal to the 1-year precipitation event (based on precipitation magnitude and frequency computations by Bonnin and others, 2004)]

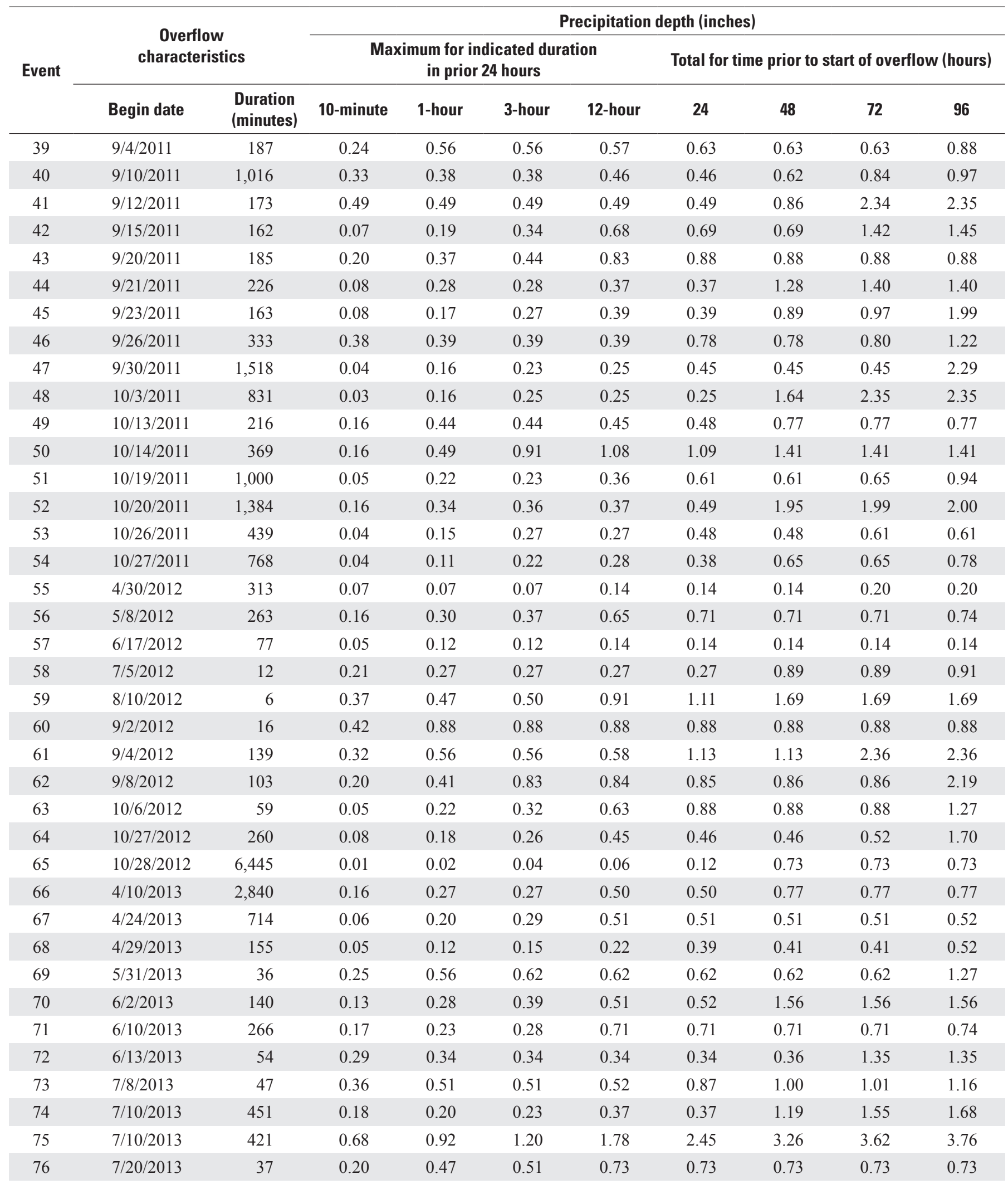


Table 1. Rain garden overflow time, duration, and precipitation-event depths, Sterncrest Drive SR1 site, Cuyahoga County, Ohio, 2008-13.-Continued

[The durations of the precipitation depths are based on the start time of the overflow. Red highlight, greater than or equal to the 10-year precipitation event; green highlight, greater than or equal to the 2-year precipitation event; yellow highlight, greater than or equal to the 1-year precipitation event (based on precipitation magnitude and frequency computations by Bonnin and others, 2004)]

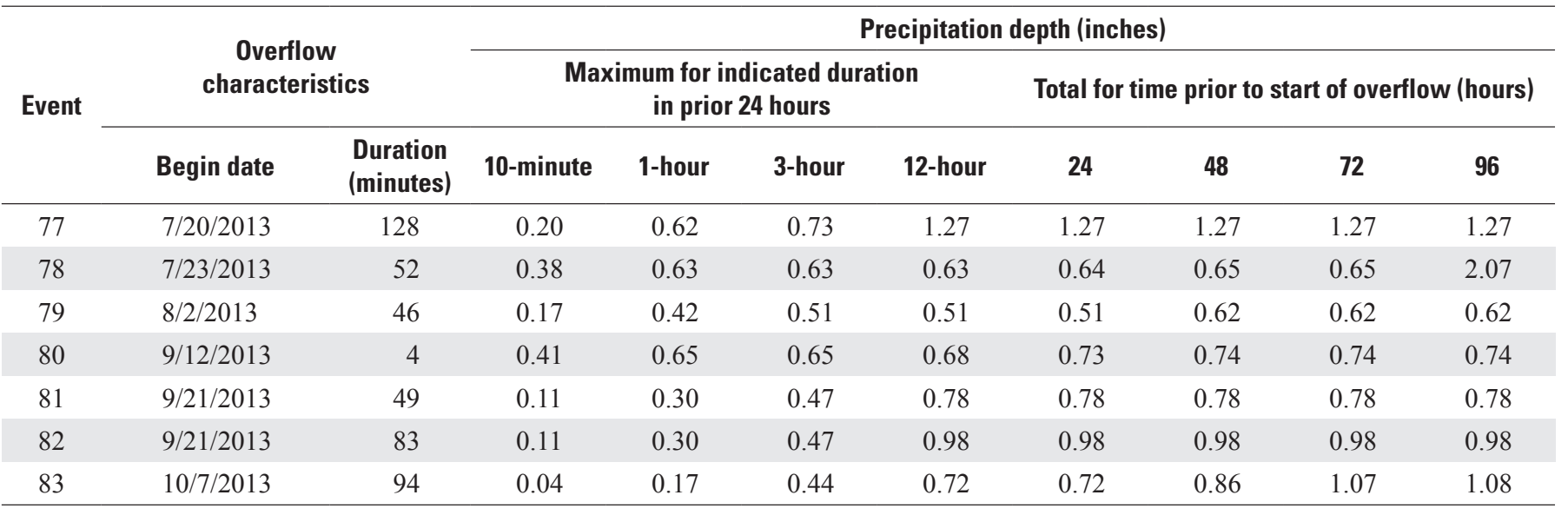

Table 2. Rain garden overflow time, duration, and precipitation-event depths, Sterncrest Drive SR2 site, Cuyahoga County, Ohio, 2008-12.

[The durations of the precipitation depths are based on the start time of the overflow]

\begin{tabular}{|c|c|c|c|c|c|c|c|c|c|c|}
\hline \multirow[b]{2}{*}{ Event } & \multirow{2}{*}{\multicolumn{2}{|c|}{$\begin{array}{c}\text { Overflow } \\
\text { characteristics }\end{array}$}} & \multicolumn{8}{|c|}{ Precipitation depth (inches) } \\
\hline & & & \multicolumn{4}{|c|}{$\begin{array}{l}\text { Maximum for indicated duration } \\
\text { in prior } 24 \text { hours }\end{array}$} & \multicolumn{4}{|c|}{$\begin{array}{c}\text { Total for time prior to start of overflow } \\
\text { (hours) }\end{array}$} \\
\hline 1 & $8 / 10 / 2009$ & 15 & 0.42 & 1.11 & 1.11 & 1.11 & 1.11 & 1.39 & 1.52 & 1.52 \\
\hline 4 & $4 / 26 / 2010$ & 8 & 0.23 & 0.52 & 0.55 & 0.72 & 0.88 & 1.23 & 1.23 & 1.23 \\
\hline 5 & $5 / 14 / 2010$ & 15 & 0.68 & 0.70 & 0.88 & 0.88 & 0.94 & 0.94 & 1.58 & 1.58 \\
\hline 6 & $6 / 6 / 2010$ & 12 & 0.48 & 0.48 & 0.74 & 0.77 & 0.77 & 0.92 & 0.92 & 0.94 \\
\hline 7 & 4/16/2011 & 2 & 0.03 & 0.09 & 0.15 & 0.15 & 0.15 & 0.15 & 0.15 & 0.16 \\
\hline 11 & $6 / 7 / 2011$ & 4 & 0.45 & 1.26 & 1.26 & 1.26 & 1.26 & 1.26 & 1.26 & 1.26 \\
\hline 12 & $8 / 6 / 2011$ & 3 & 0.12 & 0.18 & 0.18 & 0.18 & 0.18 & 0.18 & 0.19 & 0.88 \\
\hline 13 & 8/9/2011 & 34 & 0.13 & 0.25 & 0.25 & 0.25 & 0.35 & 0.75 & 0.75 & 0.93 \\
\hline 14 & 9/26/2011 & 71 & 0.49 & 0.87 & 0.87 & 0.88 & 1.27 & 1.27 & 1.29 & 1.71 \\
\hline 15 & $4 / 21 / 2012$ & 2 & 0.03 & 0.11 & 0.24 & 0.33 & 0.33 & 0.33 & 0.33 & 0.33 \\
\hline 16 & $9 / 2 / 2012$ & 15 & 0.42 & 0.43 & 0.43 & 0.43 & 0.43 & 0.43 & 0.43 & 0.43 \\
\hline 17 & 9/18/2012 & 4 & 0.07 & 0.16 & 0.20 & 0.48 & 0.50 & 0.50 & 0.50 & 0.51 \\
\hline
\end{tabular}




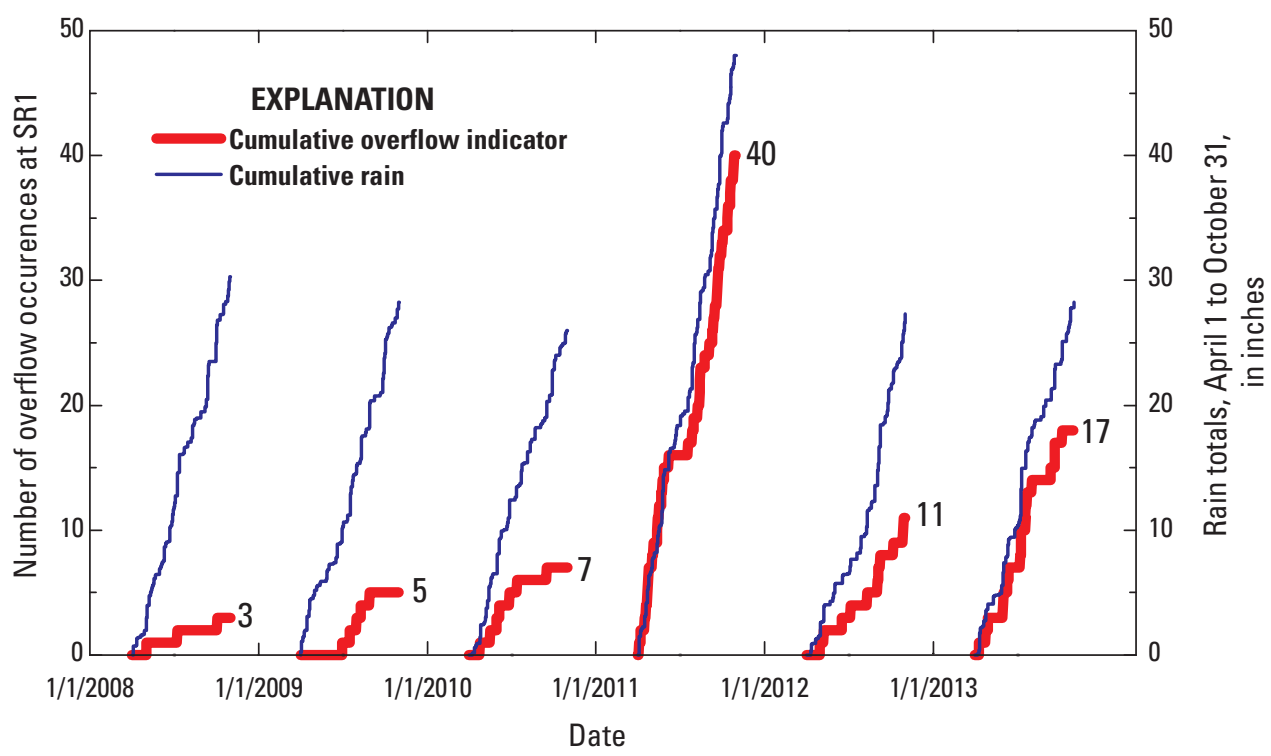

Figure 3. Cumulative overflow indicator and cumulative rain from April 1 to 0 ctober 31 of each year at the Sterncrest Drive SR1 site, Cuyahoga County, Ohio.

Table 3. Percentage of 0.75 inch or greater rain events that caused an overflow at SR1 with respect to event duration, Sterncrest Drive site, Cuyahoga County, Ohio.

[Rain-recurrence interval information from Bonnin and others, 2004]

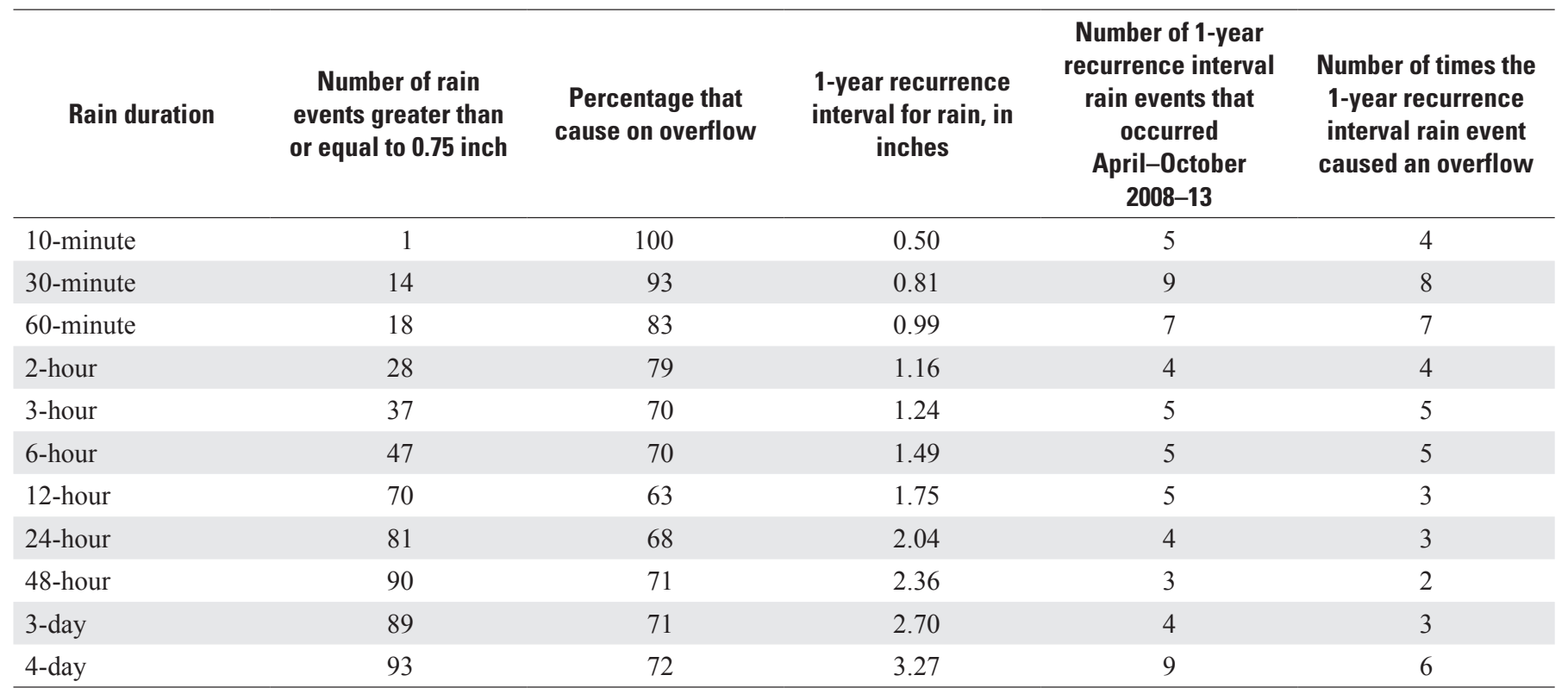




\section{Hydrologic Characteristics at the Washington Street Site}

The SCM at the Washington Street site consists of several elements that act in series to reduce runoff to receiving waters. Additional information on the site description, construction details, and methods are presented in Darner and Dumouchelle (2011). Precipitation and runoff data were collected at this site from April through September or October 2008-13.

\section{Site Description and Methods}

In 2008, the Washington Street site was undergoing construction of a commercial building and associated parking lot. The construction followed Leadership in Energy and Environmental Design (U.S. Green Building Council, 2014) principles to minimize stormwater runoff and conserve natural resources, all while maintaining an aesthetically pleasing appearance. The SCM features at the site include a rain garden, paver parking lot that is permeable (hereafter called pervious pavers) with surface and subsurface drains, a detention basin, and a vegetated swale (fig. 4). About one-half of the runoff from the roof of the building is directed to the rain garden; the remaining roof runoff drains to the swale (Darner and Dumouchelle, 2011).

Discharge from the pervious-paver subsurface drains (flume 3), overland flow from the parking lot (flume 1), and overflow from the rain garden (flume 2) (fig. 4) were determined by means of prefabricated H-flumes (fig. 5). Water levels in the flumes were measured in attached external stilling wells by means of pressure transducers connected to data loggers that initiated and stored the water-level readings. Water levels were measured every minute and, at a minimum, recorded every 10 minutes. When the stage exceeded $0.05 \mathrm{ft}$ above no flow, any change in water level of more than $0.01 \mathrm{ft}$ also was recorded. The corresponding specific conductance and water temperature were stored with each coincident waterlevel reading.

A weather station that included a heated tipping-bucket rain gage and an air-temperature sensor was maintained at the site (fig. 4). The rain gage registered precipitation in 0.01-in. increments, summed by the data logger over intervals of 10 minutes. Precipitation depths and peak intensities for 10-, 30-, 60-, 120-, and 1,440-minute intervals were determined for each precipitation event and compared to recurrence intervals determined from the tables in Bonnin and others (2004).

During construction of the parking lot, two clusters of three time-domain reflectometer (TDR) sensors were permanently installed in the permeable base under the pavers. The TDR determines soil-moisture content by measuring the permittivity, or dielectric constant, of the soil resulting from changes in soil moisture. Sensors in each cluster were installed at different depths (Darner and Dumouchelle, 2011, table 5) below the ground surface to facilitate analysis of the depth-dependent wetting characteristics of the permeable base material above the subsurface drains. The TDRs were controlled by a data logger that computed and recorded moisture content every 10 minutes.

Rain-event and runoff-event characteristics were compared using centroid lag time. Centroid lag time is defined as the time, in minutes, between the centroid of precipitation and the centroid of the flume flow (runoff). Centroid lag time is a measure of how quickly water moves off or through the impervious surfaces and other drainage routes to the discharge points. See Darner and Dumouchelle (2011) for a more detailed explanation.

\section{Data Analysis and Interpretation}

Data from this site were analyzed for April-October 2009 and 2010 and were presented in Darner and Dumouchelle (2011). Additional data were collected from April 1, 2011 through September or October 2011. During the entire period, no measurable runoff was recorded in flume 1 (which measures surface runoff from the pervious pavers) indicating all precipitation that fell on the parking lot was either infiltrated or lost to evaporation. The runoff data from flume 2 were included with the data from flume 3 to represent the total runoff from the site.

Rainfall metrics were used to capture the temporal dynamics of storm events and how these might have affected runoff processes. These metrics include the event rainfall depth, which was the amount of rain that fell during individual runoff events; and Rain ${ }_{w s}$, which is defined as the depth of rain that fell over the warm-season of a given year (starting April 1 and ending October 31). In Darner and Dumouchelle (2011), the reduction in runoff was evaluated using a runoff ratio (RR) and the delay in runoff was evaluated using centroid lag time; detailed descriptions of the derivation and basis for these metrics are described in the earlier report (Darner and Dumouchelle, 2011).

The RR at this site was defined as the total volume of runoff divided by the total volume of rain that fell on the roof and parking lot, and is the complement of percent removal, although the RR is not expressed as a percentage. The RR characterizes each runoff event with a number between 0 and 1. The closer the RR is to 0 or the percent removal to 100 , the greater the amount of runoff removed through evapotranspiration (ET) or infiltration. In this report, the percent removal is used to quantify the proportion of runoff that the SCM detained or otherwise prevented from flowing to receiving waters as direct runoff. The percent removal is defined as the volume of water removed from the runoff through ET, infiltration, or other losses within the treatment system and is described by

$$
\text { percent removal }=100 *\left(V_{\text {in }}-V_{\text {out }}\right) / V_{\text {in }}
$$

where

$$
\begin{array}{ll}
V_{\text {in }} & \text { is the volume of water from rain, and } \\
V_{\text {out }} & \text { is the volume of water leaving the SCM. }
\end{array}
$$




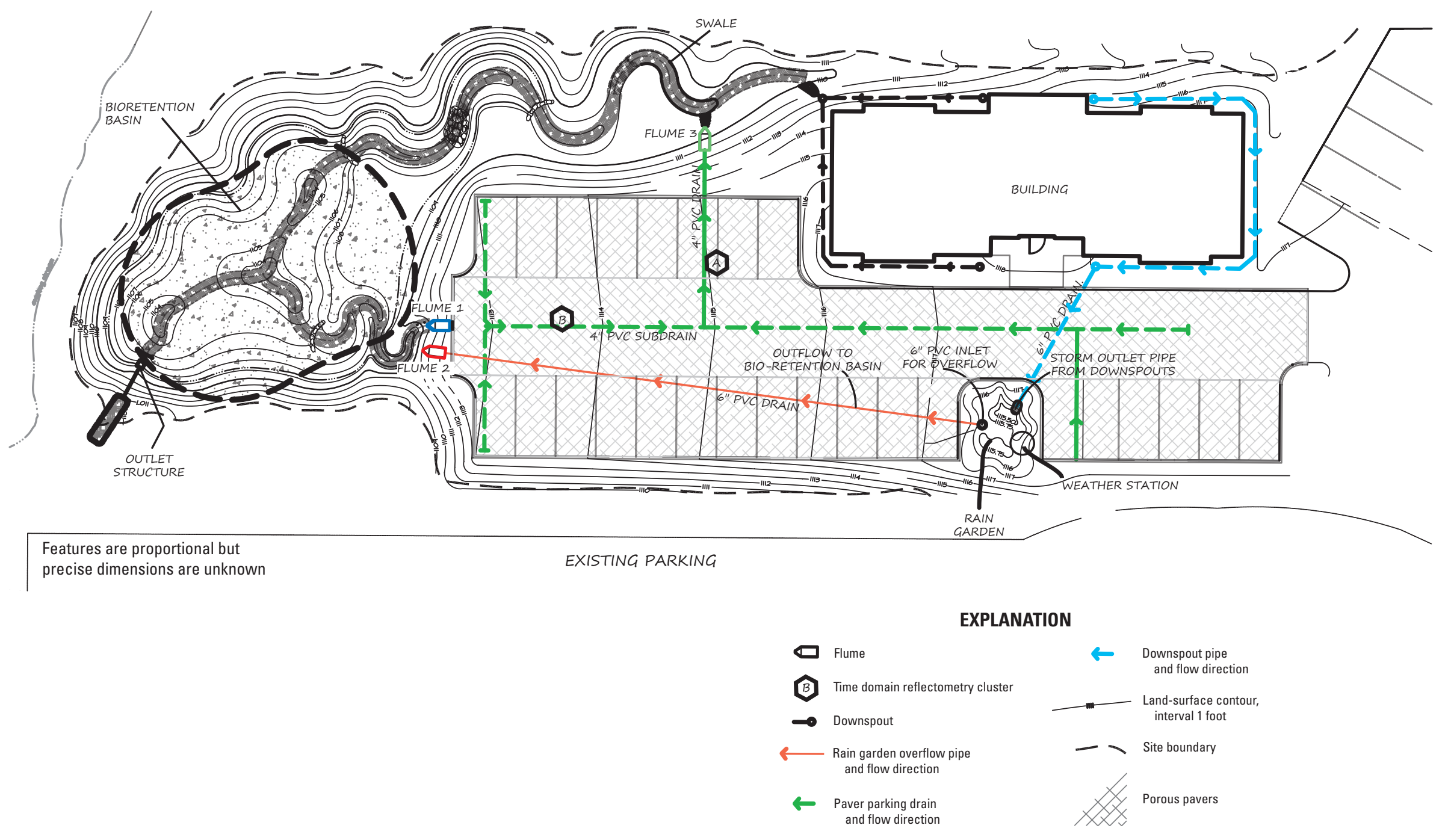

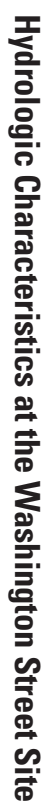

Figure 4. Schematic site plan for stormwater best-management practices at the Washington Street site, Geauga County, Ohio. 


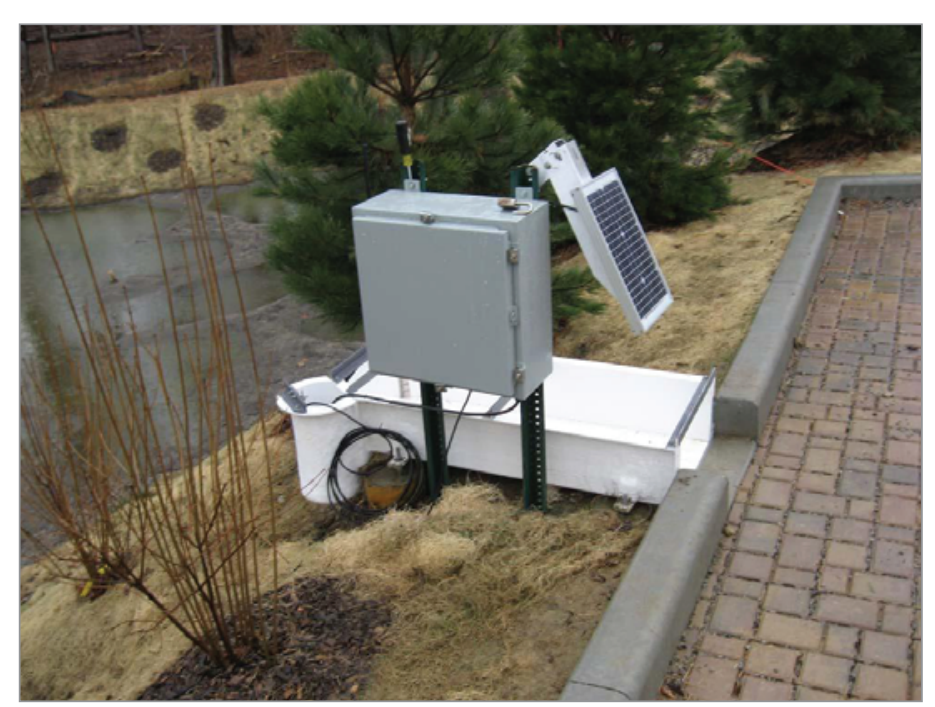

A. Flume 1

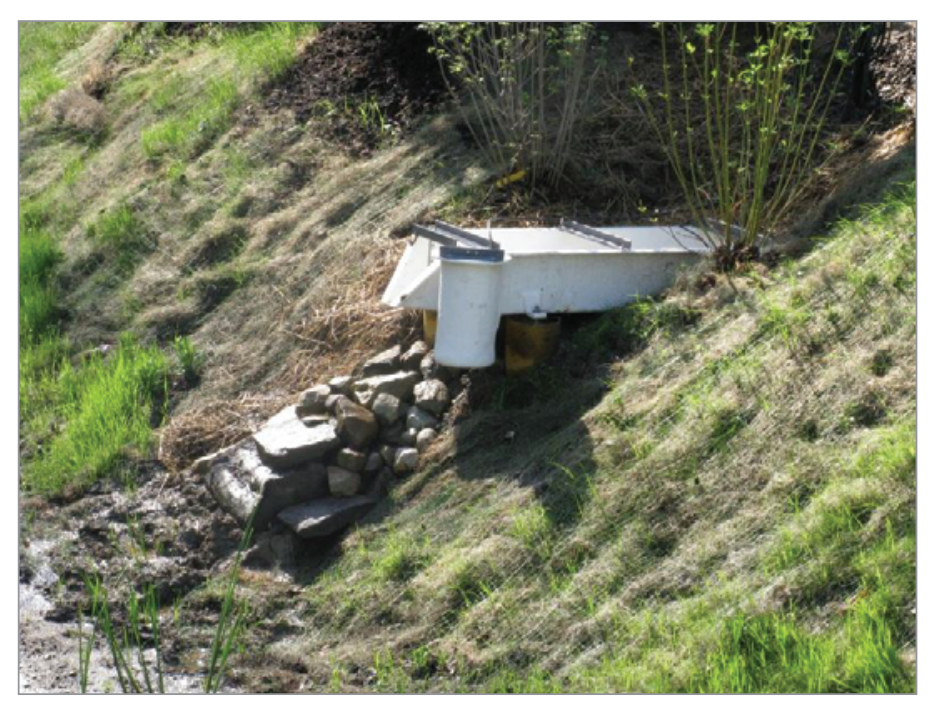

B. Flume 2

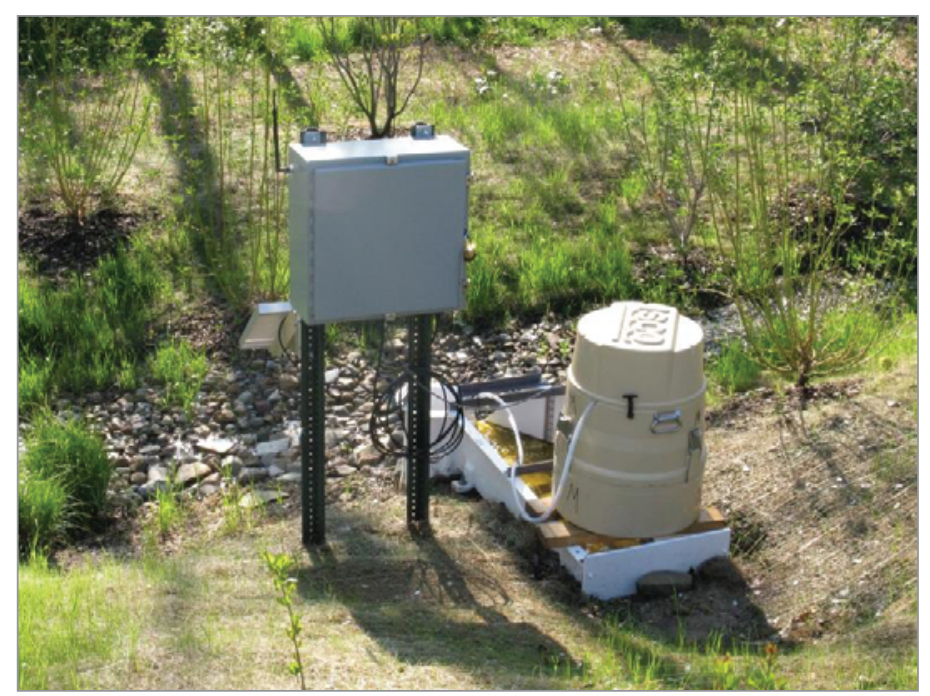

C. Flume 3

Figure 5. Three flumes at the Washington Street site, Geauga County, Ohio. A, Flume 1 measures surface flow over the parking lot. $B$, Flume 2 measures any overflow from the rain garden. $C$, Flume 3 measures the flow from the drain line. 
Standard statistical techniques were used to perform exploratory data analysis, analysis of variance, and correlation on datasets that include volume, soil moisture, precipitation totals and duration, and lag times. An alpha level of 0.05 was used in all tests of statistical significance.

Rain events with totals less than 0.2 in. were excluded from the analysis. There were few rain events with depths less than 0.2 in. (6 percent in 2010, 10 percent in 2011, 7 percent in 2012, and 7 percent in 2013). The instrumentation used to measure stage in the flumes was not sensitive enough to measure the runoff from rainfall events less than $0.2 \mathrm{in}$. All rain events less than or equal to 0.20 were dropped from the analysis because their impact on discharge cannot be accurately measured. However, it is important to note even small rain events may have acted to increase soil moisture content and subsequently reducing infiltration capacity. This would potentially lead to shorter centroid lag times due to reduced infiltration capacity in the system, which may be manifested as a decrease in the percent reduction for the next rain event.

The Washington Street SCM is intended to reduce and (or) delay the runoff from the building and parking lot. Figure 6 is a boxplot of percent removal and bar graph of Rain ${ }_{\mathrm{ws}}$ by year. The mean amount of rain for the northeast region of Ohio for the months of April-October is 24.19 in. (National Oceanic and Atmospheric Administration, 2002). Rain ${ }_{\text {ws }}$ for 2011 was
43.74 in., an increase of nearly 45 percent over average. The amount of Rain $_{\mathrm{ws}}$ in 2011 was greater than in any of the other years such that the 2011 value of Rain ${ }_{\text {ws }}$ was 93 percent of the average annual precipitation for this area of Ohio (Midwestern Regional Climate Center, 2010). The median percent removal in 2009 was slightly less than 25 percent with two outliers indicating episodically high detention of runoff volume (fig. 6). While the Rain ${ }_{\mathrm{ws}}$ in 2010 was similar to 2009, the median percent removal increased to nearly 60 percent. In 2011, the amount of Rain ${ }_{w s}$ was nearly twice that of 2009 and 2010. An analysis of variance shows that the mean percent removal in 2011 was different than in 2010 (results in appendix 1), and the notched intervals for 2009, 2010, and 2011 do not overlap indicating that the medians are significantly different at the 95-percent confidence level. The annual mean percent removal for 2010-13 ranged from 55 to 37 percent, with an overall mean of 45 percent. Darner and Dumouchelle (2011) stated that differences in runoff volume and lag times (discussed later) observed in 2009 as compared to 2010 might have been due to changes related to the establishment of the plants in the rain garden (overcoming the shock of transplantation, increasing root and foliage mass, and generally adapting to new environmental conditions), development of preferential flow paths, and (or) differing weather conditions.
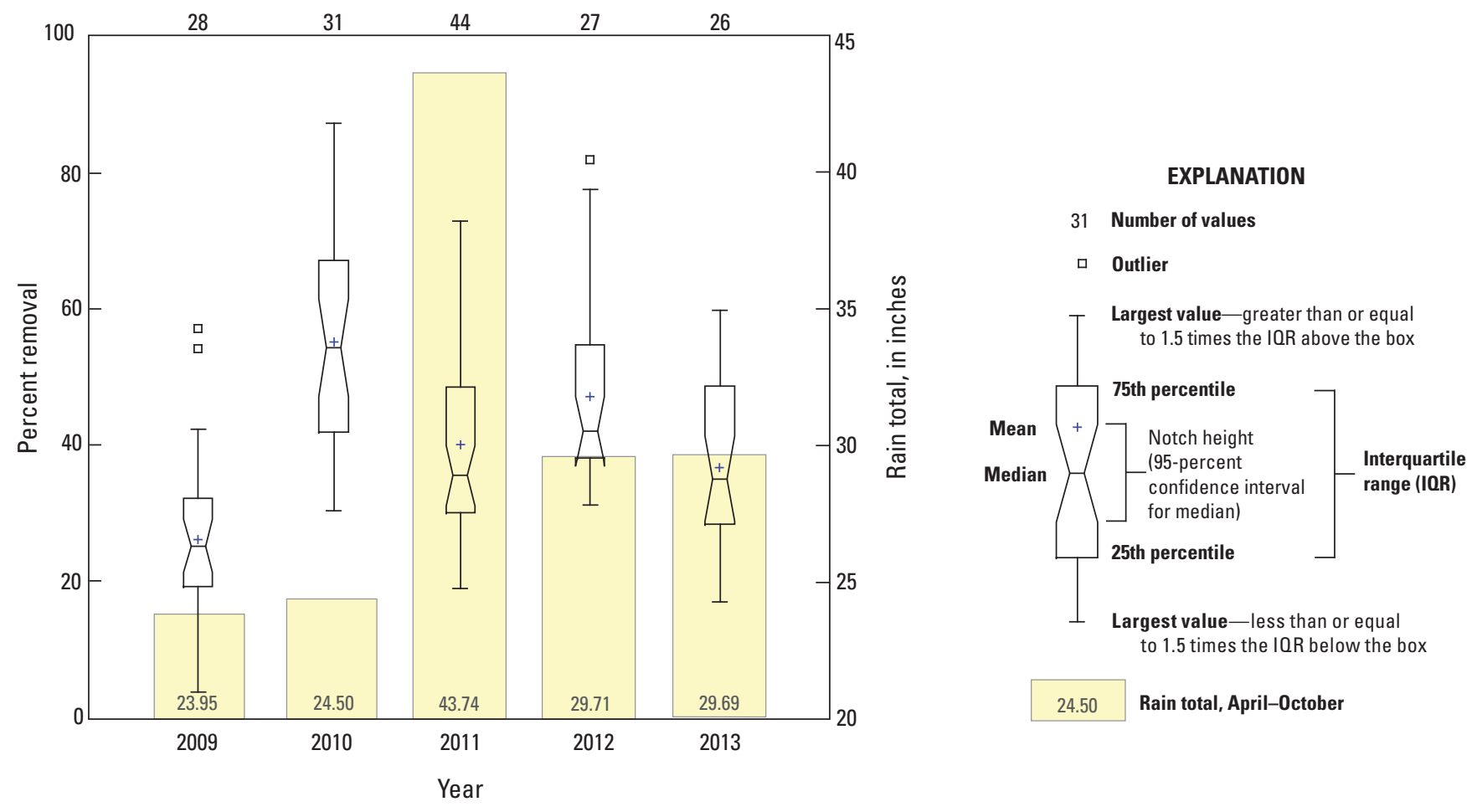

Figure 6. Percent removal and bar graph showing the depth of rain starting April 1 and ending 0 ctober 31 , by year, at the Washington Street site, Geauga County, Ohio. 
Rainfall dynamics, described by rain event totals, durations, and intensities affect the runoff characteristics at the site but with only 2 years of data in the original study (Darner and Dumouchelle, 2011) no such analysis could be performed. With additional data from 2011-13, it was possible to examine correlations between percent removal and Rain ws $_{\text {to help }}$ assess whether changes in percent removal likely were due to changes in the SCM itself, or instead due to differences in rainfall pattern. Figure 7 shows boxplots for the rain-event total rainfall, rain-event duration, and percent removal for 2010-13. The range in totals (fig. 7A) and duration of the individual rain events (fig. $7 B$ ) were similar from year to year. The rain events in 2011, while neither larger nor longer than the other years, were more frequent, which reduced the time between events for water to move through the SCM; thus, while there is a trend in decreasing percent removal, there was an increase from 2011 to 2012 (fig. 7C).
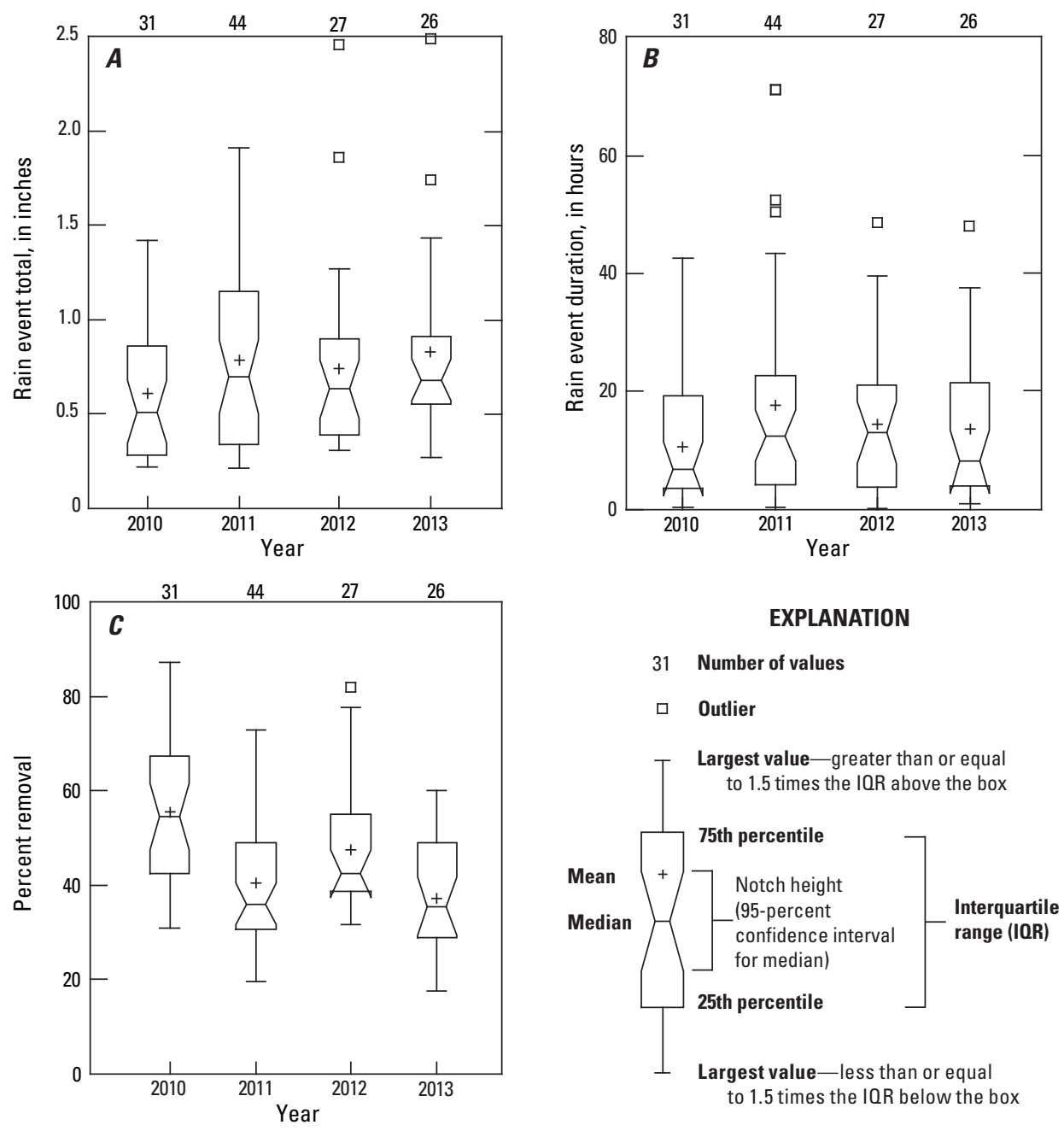

Figure 7. Climatological and flow characteristics, Washington Street site, Geauga County, Ohio, 2010-13. A, Rain-event total rainfall. $B$, Rain-event duration. $C$, Percent removal. 
Correlations (as indicated by Spearman's rank correlation coefficient) between percent removal and event rain total; event duration; rainfall in the previous $24,48,96$, and 240 hours; and maximum event rainfall for 10-, 20-, 30-, and 60-minute intervals are summarized in table 4. Also included is a term to account for the large-scale differences in total annual rainfall from year to year. The term is calculated as per

$$
L O G \_P N=\log 10\left(\text { Event Rain } * \text { Rain }_{w s}\right)
$$

$L O G \_P N$ is a cross-product term that weighs event total rain depth as a function of the seasonal total rain depth and will normalize each rain event by the total rain for the year.

During 2010-13, the rain total and $L O O_{-} P N$ are significantly correlated to percent removal, indicating that percent removal is not independent of rainfall characteristics. The amount of rain in different time periods preceding the overflow was generally not significantly correlated to percent removal, and the maximum rain totals during overflows were only significantly correlated in 2011 (for 60-minute maximum totals) and 2012 (for 20-, 30-, and 60-minute maximum totals). In 2009 , only rain duration was significantly correlated with percent removal, and in all other years there were at least three rain characteristics that were significantly correlated to percent removal (table 4). The difference in correlations plus the lower percent reduction and the presence of outliers (fig. 6) indicates that 2009 was an establishment year; therefore, the data from 2009 are presented for completeness, but have been excluded from further analyses.
The effect of the rain total on percent removal also can be seen in plots of the data (fig. 8). In every year, as the event totals increase, the percent removal decreases. While it appears in figure $8 A$ that the slope in 2010 is different, it is statistically the same as the other years at the 95-percent confidence interval (data not shown). It is interesting to note that the slopes are similar between the years indicating that the relation between rain-event size and percent-removal decline is consistent over time. The decline in percent removal from year to year can be observed on these plots by the decrease in the y-intercepts from 2010 to 2013.

To assess whether factors other than rain totals were associated with observed changes in percent removal over the 4 years, a linear regression was done to remove the variance in percent removal associated with rainfall totals (results in appendix 1, section B) and LOG_PN (results in appendix 1, section $\mathrm{C}$ ). The regression with rain total, while significant, only explains about 25 percent of the variance in percent removal. The regression of $L O G \_P N$ only explains about 35 percent of the variance in percent removal but when other rain characteristics were added as part of a multiple linear regression (MLR), the results did not improve (results of MLR not shown). The residuals (observed minus predicted values) from the linear regression of percent removal as the dependent variable and $L O G_{-} P N$ as the independent variable represent percent removal with the effects of $L O G_{-} P N$ removed, and boxplots of the residuals by year (fig. 9) show a declining percent removal over time. Analysis of variance of the residuals indicated that there was indeed a significant decline in percent removal from 2010 to 2013 and from 2012 to 2013 (results in appendix 1, section $\mathrm{C}$ ).

Table 4. Spearman correlations of percent removal to measure antecedent conditions and rain intensity for events with total rainfall greater than or equal to 0.2 inches at the Washington Street site, Geauga County, Ohio.

[Green text indicates statistical significance at alpha $<0.05$; Rain ${ }_{w s}$, depth of rain from April 1 to October 31 in any given year]

\begin{tabular}{|c|c|c|c|c|c|c|}
\hline & 2009 & 2010 & 2011 & 2012 & 2013 & 2010-13 \\
\hline Duration (hours) & -0.40 & -0.30 & -0.19 & -0.07 & -0.47 & -0.32 \\
\hline Total rain (inches) & -0.32 & -0.48 & -0.47 & -0.56 & -0.53 & -0.38 \\
\hline${ }^{1} \mathrm{P} 48$ & 0.18 & -0.04 & 0.09 & 0.21 & 0.15 & 0.08 \\
\hline${ }^{1} \mathrm{P} 96$ & 0.03 & -0.10 & 0.01 & 0.04 & 0.04 & 0.05 \\
\hline${ }^{2} \mathrm{X} 10$ & -0.17 & -0.15 & -0.14 & -0.35 & -0.12 & -0.05 \\
\hline${ }^{2} \mathrm{X} 20$ & -0.16 & -0.18 & -0.22 & -0.42 & -0.12 & -0.08 \\
\hline${ }^{2} \mathrm{X} 30$ & -0.22 & -0.24 & -0.29 & -0.49 & -0.10 & -0.10 \\
\hline${ }^{2} \mathrm{X} 60$ & -0.19 & -0.26 & -0.36 & -0.56 & -0.04 & -0.15 \\
\hline LOG_PN ${ }^{3}$ & -0.32 & -0.48 & -0.47 & -0.56 & -0.53 & -0.34 \\
\hline
\end{tabular}

${ }^{1} \mathrm{P} \#$ is the amount of rain in \#-hour period preceding the event, in inches.

${ }^{2} \mathrm{X} \#$ is the maximum \#-minute rain total for the event, in inches.

${ }^{3} \log 10$ (Event Rain/Rain ${ }_{w s}$ ). 


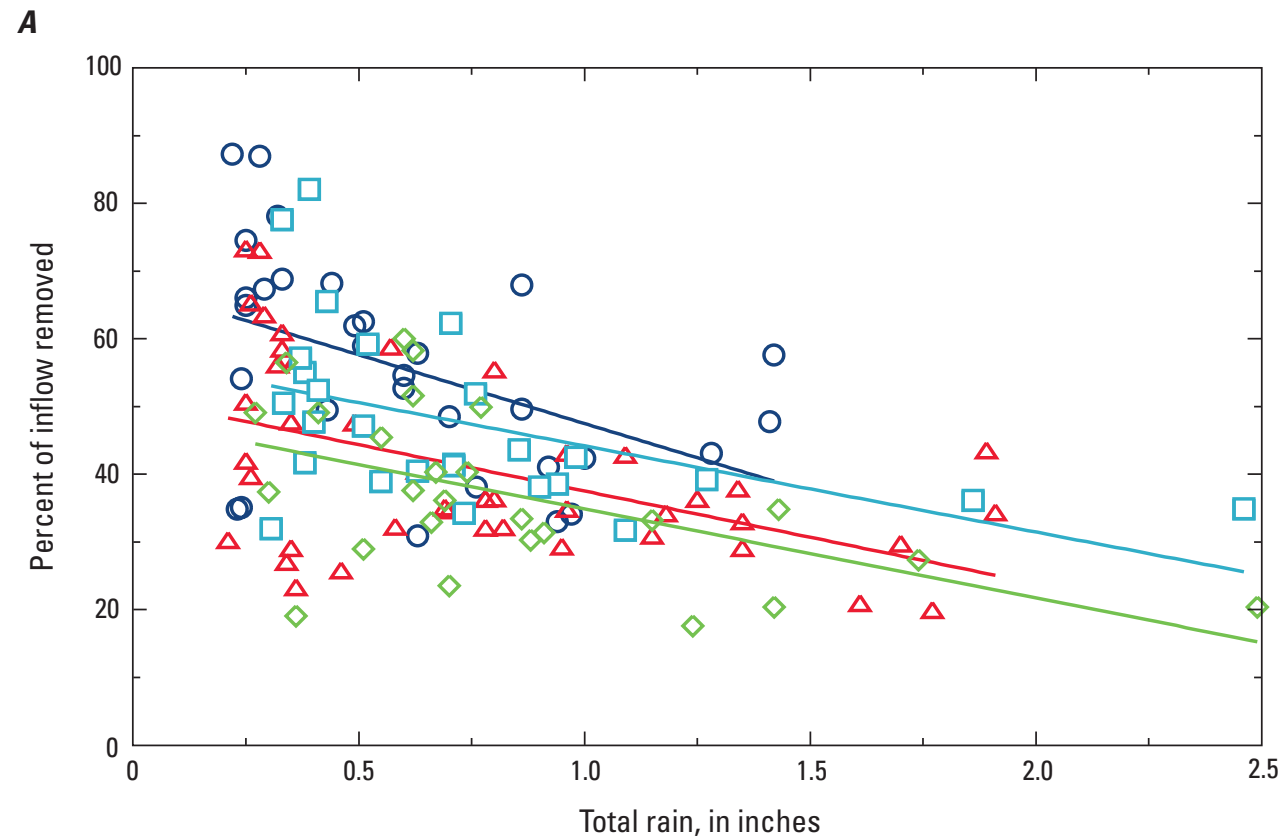

B

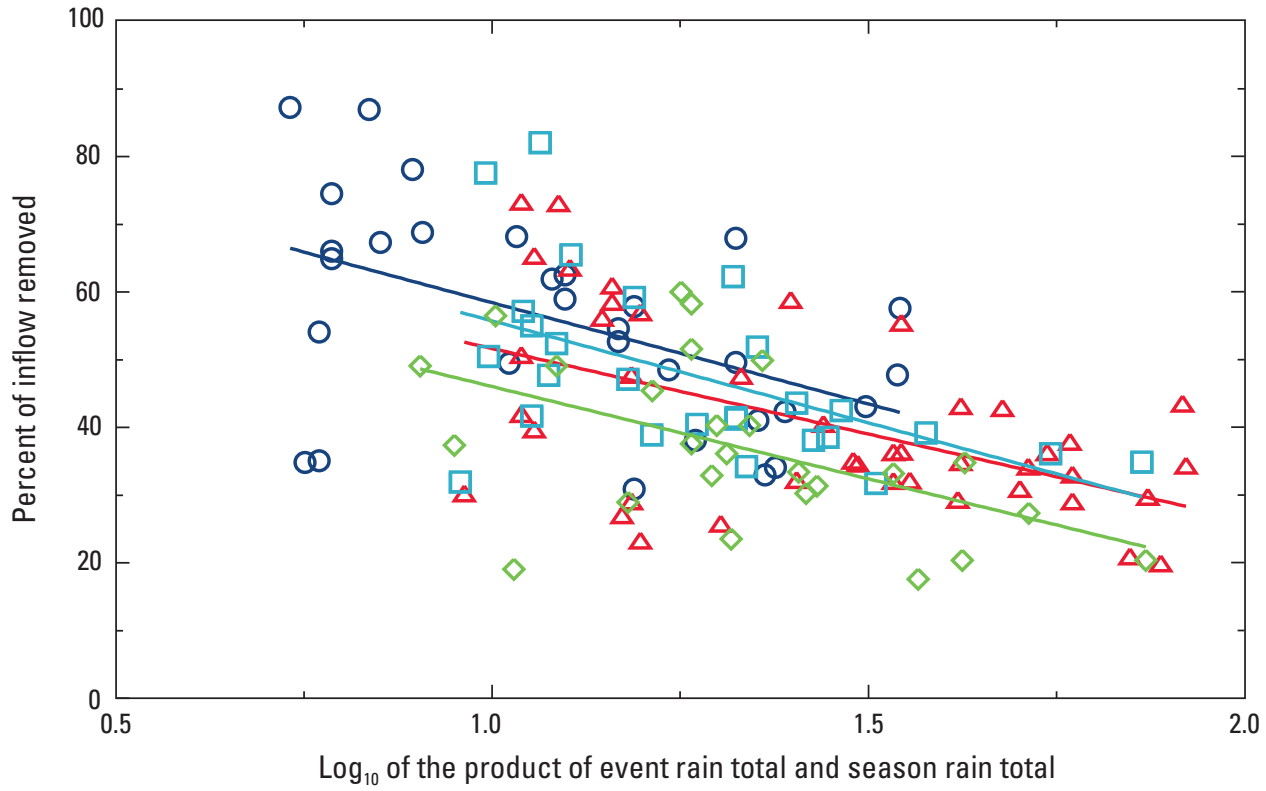

\section{EXPLANATION}

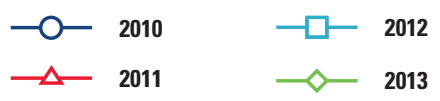

Figure 8. Scatter plots and fit linear least-squares lines for 2010-13, Washington Street site, Geauga County, Ohio. A, Percent removal and rain event total. $B$, Percent removal and $\log _{10}$ of the product of event rain total and season rain total. 


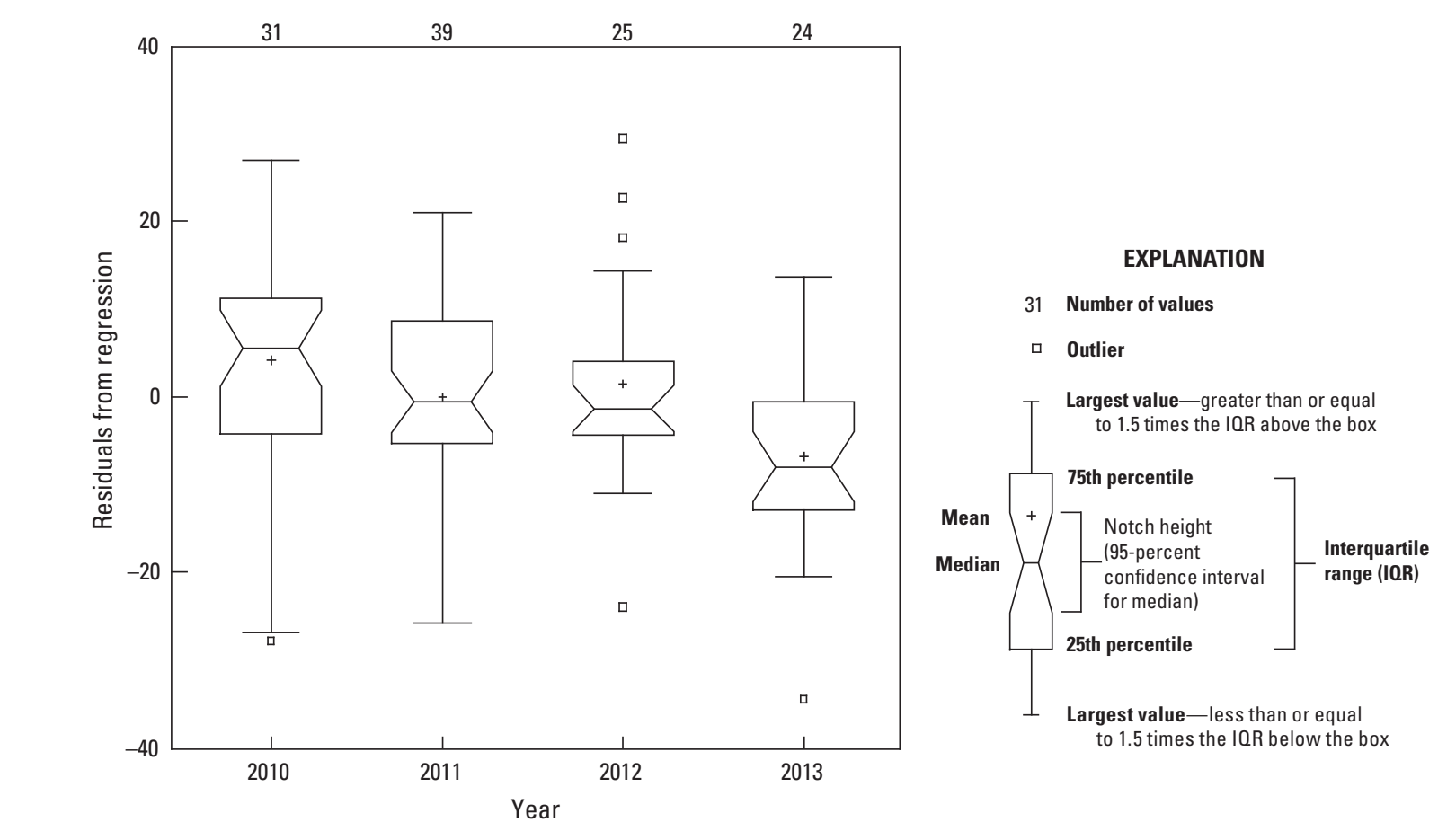

regression equation Percent Removal $=-31.3 \times \log _{10}($ Event Rain $\times$ (total rain April to October $\left.)\right)+85.6$

Figure 9. Percent removal residuals, by year, at the Washington Street site, Geauga County, Ohio.

Declines in percent removal over time could result from increased runoff due to clogging of the gravel substrate that underlies the pervious-paver system. Although it is not possible to determine if any clogging has occurred without removing the pavers, the data from the soil-moisture sensors may indicate that fine-grained sediments could be collecting in parts of the pervious-paver system. Increases in soil moisture recorded by the sensors in the gravel under the pavers may indicate that sediments are collecting in pore spaces and impeding infiltration of water through the gravel layer, because fine-grain sediments retain water better than coarsegrain gravels. Figure 10 shows the baseline (soil-moisture value the hour before rain started) data from the soil-moisture sensors. The baseline moisture in cluster A does not change much over the years. In cluster B, there is a rise in the baseline moisture in the shallowest sensors indicating that fines collect above a depth of $2.7 \mathrm{ft}$ in the system near cluster B. Cluster B is located (fig. 4) in the lower (downgradient) portion of the parking lot where fines that are carried in sheet flow over the pavers would tend to settle and collect.

The Washington Street SCM not only increases the immediate removal of runoff through infiltration into pervious pavers and soils that underlay the rain garden, but also delays the onset of runoff. The delay in runoff can be examined by comparing the temporal dynamics of runoff and its duration.
Antecedent moisture conditions affect the time between the onset of rainfall and discharge from the SCM; therefore, the centroid of the rain event and centroid of the resulting runoff were used to normalize the effect of antecedent conditions, rain intensity, and duration. The centroid lag time is the time, in minutes, between the centroid of precipitation and the centroid of flume flow (runoff). The centroid lag time is an indicator of how long it takes for rain to pass through the SCM. With the exception of 2011, the median centroid lag was generally between 280 and 320 minutes, and there is no apparent trend to the centroid lag times (fig. 11A). Lag time typically will change as a function of the duration of the rainfall event. All other things being equal, as the duration of a rain event increases, so does the centroid lag time. Any observed trends in lag times may merely reflect trends in the duration of rainfall events. Consequently, to adjust for the rain duration effect, centroid lag times were normalized by rain durations (fig. 11B). Normalizing the lag times by the duration of the rain events indicates that differences in rain patterns over the years affected the centroid lag times; the median normalized lag time is similar for all 4 years $(0.55,0.52,0.54$, and 0.47 for 2010-13, respectively). The duration of rain events in 2011 is the determining factor in why the lag times were significantly longer than the other years. 
Cluster A

A. $1.3 \mathrm{ft}$

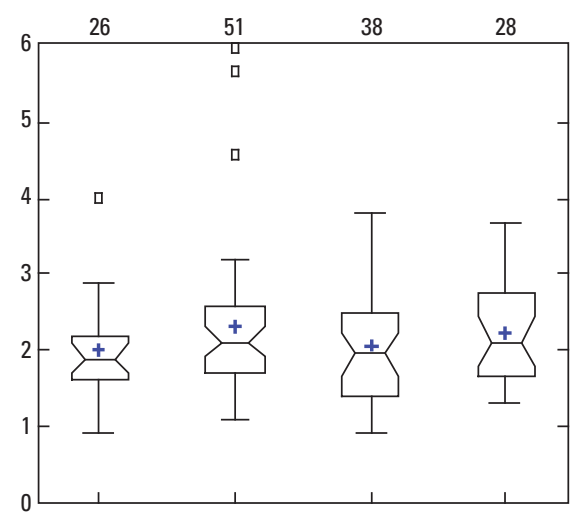

B. $1.5 \mathrm{ft}$

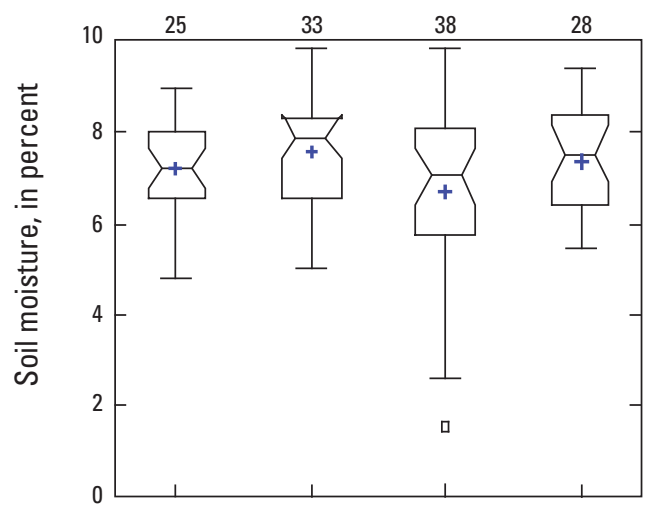

C. $2.8 \mathrm{ft}$

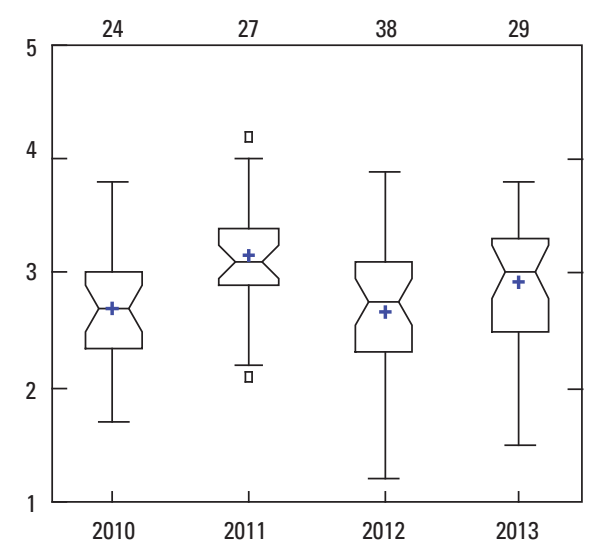

Cluster B

D. $1.5 \mathrm{ft}$

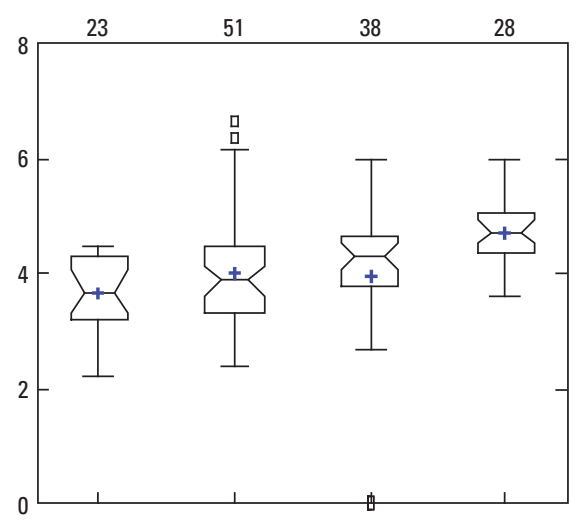

E. $1.7 \mathrm{ft}$

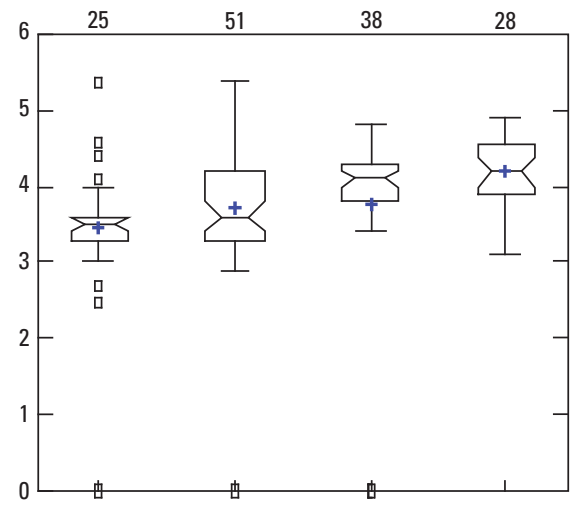

F. $2.7 \mathrm{ft}$

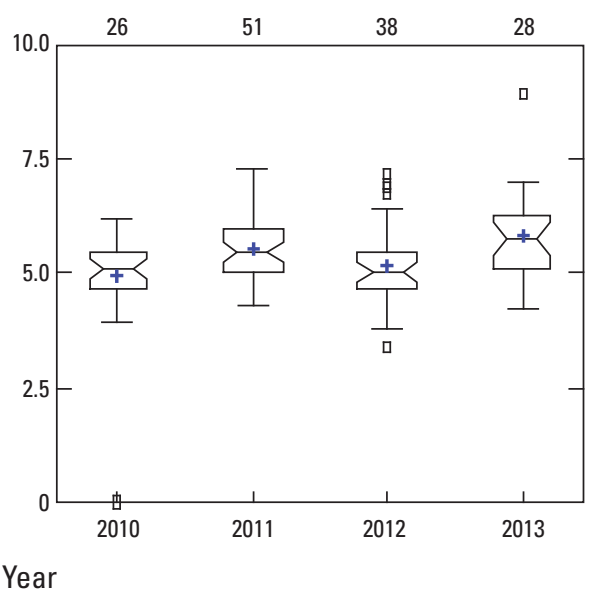

EXPLANATION

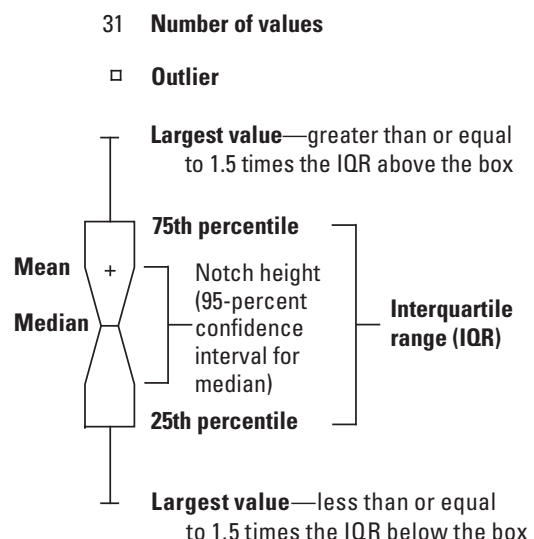

Figure 10. Baseline moisture in soil-moisture sensors, Washington Street site, Geauga County, Ohio, 2010-13. 
$\boldsymbol{A}$

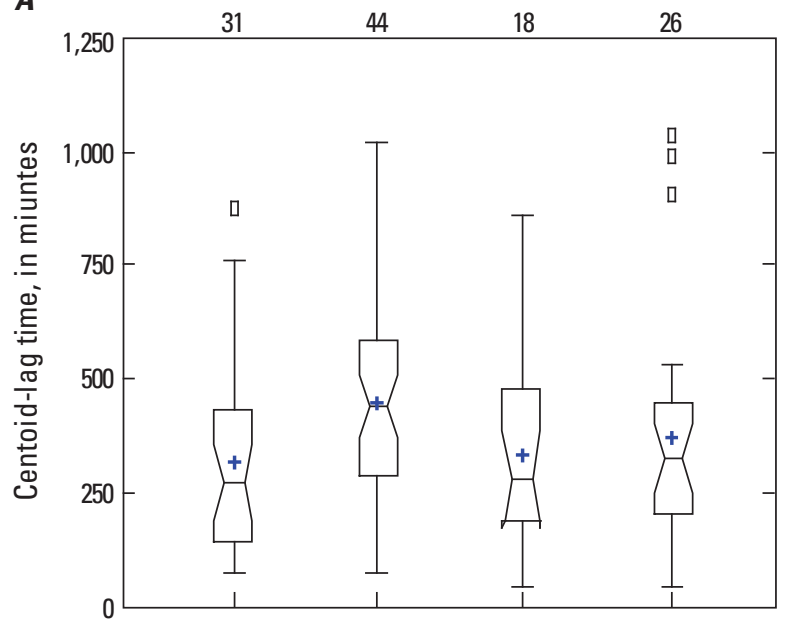

B
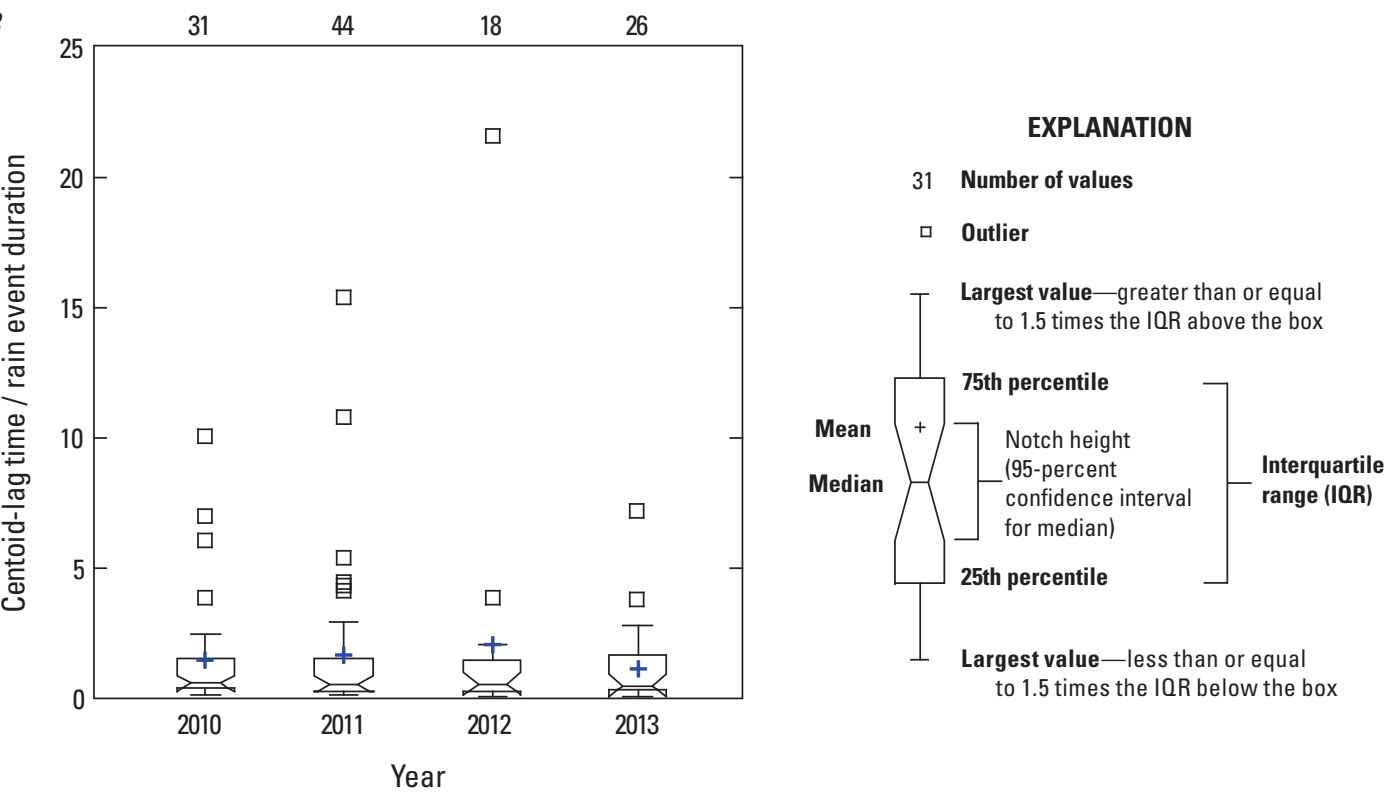

Figure 11. Precipitation-runoff centroid lag times for the Washington Street site, Geauga County, Ohio, 2010-13. A, In minutes. B, Rain event duration. 
As has been discussed, the data show that the percent removal has been declining over time at the Washington Street $\mathrm{SCM}$. The behavior of the rain garden and the pervious-paver system of the SCM can be investigated by examining the data from flumes 2 and 3 (fig. 4). The volume of water that overflowed the rain garden (flume 2) was similar for 2010, 2012, and 2013 but was more than 2.5 times greater in 2011 (fig. 12). The larger volume of water in flume 2 in 2011 is not extraordinary, given the greater rainfall in 2011 and the smaller demand for water by the plants (i.e., less transpiration). Likewise, volumes through flume 3 were highest in 2011; however, the volume of water that drained from the pervious-paver system (flume 3) increased from 2010, to 2012 and 2013. Thus, the flume data indicate that the decline in the percent removal of the SCM is a function of the pervious-paver system; however, the exact cause is not known. Although the runoff increased (percent removal decreased) over time, the lag time remained fairly constant over time and therefore more water (runoff) moved through the system in roughly the same time, indicating that preferential flow paths have likely developed within the SCM.

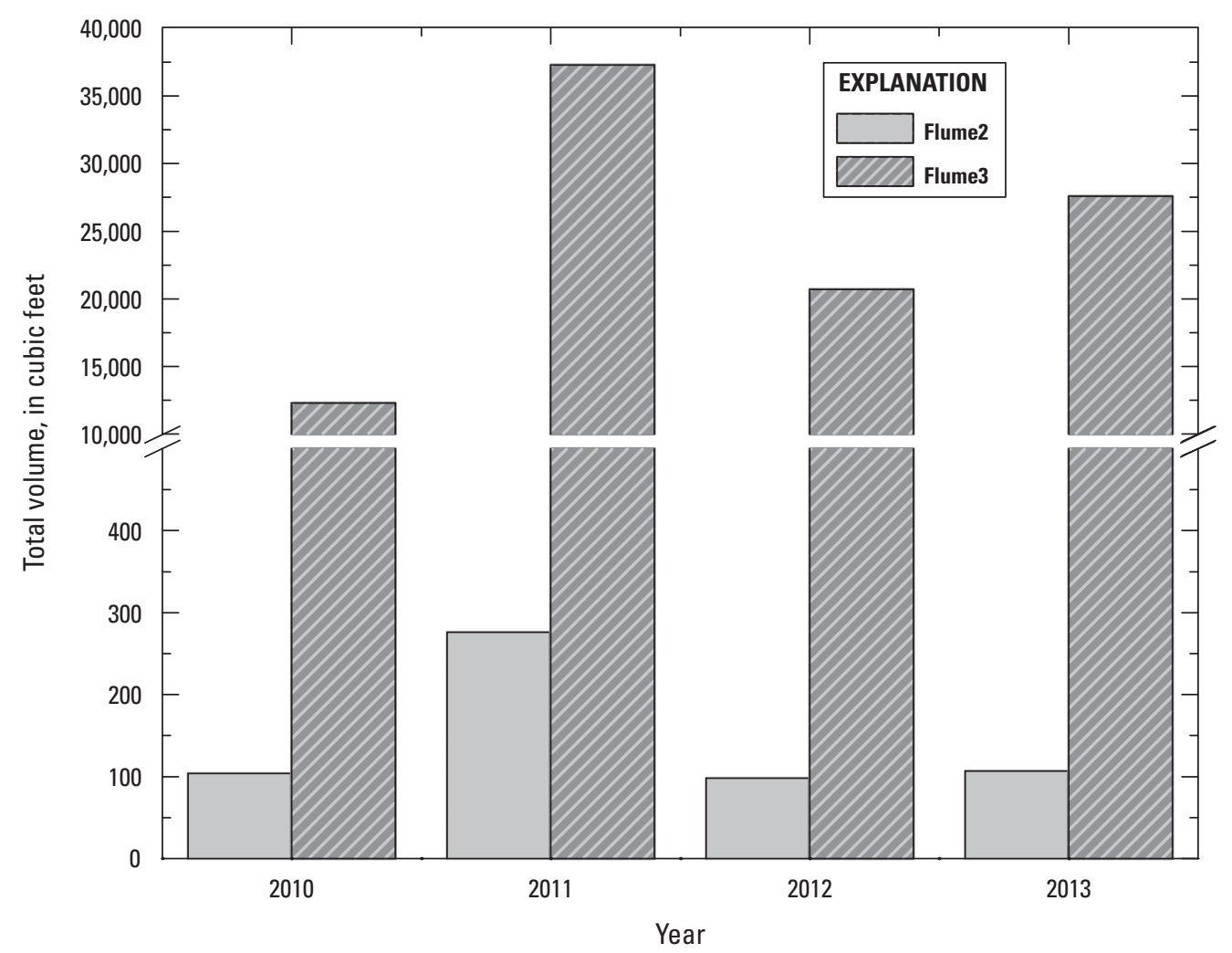

Figure 12. Total flow through flumes 2 and 3 for April-0ctober 2010-13 at the Washington Street site, Geauga County, Ohio. 


\section{Summary and Conclusions}

The movement of water through retrofit low-impact development (LID) system installations was monitored at two sites in suburban areas of the greater Chagrin River watershed. Selected metrics were used to document LID system performance with regard to stormwater-volume management objectives at each site. Rain-garden overflow frequency data from the Sterncrest Drive site were used to characterize system performance relative to rainfall patterns, and to highlight certain design features that may restrict flow in the stormwater-control measures (SCM). Overflows at the site generally increased during the study; however, some of this increase was due to increases in the total precipitation in some years, specifically 2011. The small drainage pipes (8-in.) on the north side of Sterncrest Drive likely played a role in the greater number of overflows at SR1 as compared to SR2. Although the storm duration associated with the 0.75 inch (in.) design storm was not specified, approximately 70 percent of the storms equaling or exceeding $0.75 \mathrm{in}$. over 3 hours or more resulted in an overflow at SR1. Clogging of the surface or subsurface sediments of the SCM could account for some of the increases in overflows; however, the pipes were not excavated to verify clogging. Overall, monitoring data and local observations demonstrate the continued success of the SCM in preventing roadway closure due to flooding through the warm season of 2013. If clogging is the primary factor for increasing overflow, then the system may be inadequate to meet local objectives of reduced street flooding in future years. Additional monitoring would help to quantify the SCM functionality over time.

The additional years of data collected at the Washington Street site illustrate the importance of longer-term monitoring in order to understand system dynamics and avoid premature conclusions. In the initial analysis of 2 years of data (2009-10) from the SCM at the Washington Street site, an increase in the percent removal (decrease in runoff) and a decrease in lag times (faster runoff) was observed; however, based on the additional data from 2011-13, it seems likely that the first year (2009) was an establishment year for the system. The analysis of the additional years of data also show that, while variations in rainfall may have an impact in any single year, it appears that system performance with respect to runoff removal is decreasing; however, the lag time between the centroid of precipitation and runoff remained fairly constant. The combination of decreased removal of runoff and no change in the timing of runoff production may be due to the development of preferential flow paths (short circuits) within the system. The SCM at the Washington Street site was designed to reduce and (or) delay runoff and it is still meeting those goals despite a decrease in the reduction of runoff over time. Similar to the SCM at the Sterncrest Drive site, additional monitoring at this site would help to establish the SCM functionality over time, specifically the pervious-paver component.

\section{References Cited}

Ahern, J., 2007, Green infrastructure for cities - The spatial dimension, in Cities of the future towards sustainable water and landscape management, Novotny V., and Brown, P., eds.: London, IWA Publishing, p. 267-283.

Bonnin, G.M.; Martin, Deborah; Lin, Bingzhang; Parzybok, Tye; Yekta, Michael; and Riley, David, 2004, Precipitationfrequency atlas of the United States: Silver Spring, Md., National Oceanic and Atmospheric Administration, National Weather Service, NOAA Atlas 14, v. 2, ver. 3, accessed September 19, 2014, at http://www.nws.noaa.gov/oh/hdsc/ currentpf.htm.

Booth, D.B., and Jackson, C.R., 1997, Urbanization of aquatics - Degradation thresholds, stormwater detention, and limits of mitigation: Journal of the American Water Resources Association, v. 33, p. 1077-1090.

Darner, R.A., and Dumouchelle, D.H., 2011, Hydraulic characteristics of low-impact development practices in northeastern Ohio, 2008-2010: U.S. Geological Survey Scientific Investigations Report 2011-5165, 19 p.

Dietz, M.E., 2007, Low impact development practices-A review of current research and recommendations for future directions: Water, Air, and Soil Pollution, v. 186, no. 1-4, p. 351-363.

Fletcher, T.D.; Shuster, William; Hunt, W.F.; Ashley, Richard; Butler, David; Arthur, Scott; Trowsdale, Sam; Barraud, Sylvie; Semadeni-Davies, Annette; Bertrand-Krajewski, Jean-Luc; Mikkelsen, P.S.; Rivard, Gilles; Uhl, Mathias; Dagenais, Danielle; and Viklander, Maria, 2014, SUDS, LID, BMPs, WSUD and more - The evolution and application of terminology surrounding urban drainage: Urban Water Journal, DOI: 10.1080/1573062X.2014.916314, accessed August 12, 2014, at http://www.tandfonline.com/ doi/full/10.1080/1573062X.2014.916314.

Jagucki, M.L., and Darner, R.A., 2001, Ground-water quality in Geauga County, Ohio; review of previous studies, status in 1999, and comparison of 1986 and 1999 data: U.S. Geological Survey Water-Resources Investigations Report 01-4160, 61 p.

Midwestern Regional Climate Center, 2010, Station 331657 Cleveland Hopkins, and station 331458 Chardon, accessed December 30, 2010, at http://mrcc.isws.illinois.edu.

Musgrave, D.K., and Holloran, D.M., 1980, Soil survey of Cuyahoga County, Ohio: U.S. Department of Agriculture, Soil Conservation Service, 157 p., 64 sheets. 
National Oceanic and Atmospheric Administration, 2002, Climatography of the United States, no. 85, Divisional normals and standard deviations of temperature, precipitation, and heating and cooling degree days 1971-2000 (and previous normals periods), accessed December 15, 2014, at http://www.ncdc.noaa.gov/climatenormals/clim85/

CLIM85_PRCP02.pdf.
U.S. Green Building Council, 2014, LEED (Leadership in Energy \& Environmental Design) USGBC Web page, accessed December 2014 at http://www.usgbc.org/leed.

Williams, N.L., and McCleary, F.E., 1982, Soil survey of Geauga County, Ohio: U.S. Department of Agriculture, Soil Conservation Service, 169 p., 56 sheets. 


\section{Appendix 1. Statistical Output}

\section{Section A. Statistical difference of means of percent removal using the Tukey-Kramer test at the Washington Street site, Geauga County, Ohio, 2010-13.}

\begin{tabular}{|c|c|c|c|c|c|}
\hline \multicolumn{6}{|c|}{ Difference } \\
\hline YEAR & & Between & Simultaneou & Is $95 \%$ & \\
\hline Compa & rison & Means & Confidence & Limits & \\
\hline 2010 & - 2012 & 6.039 & -2.706 & 14.783 & \\
\hline 2010 & - 2011 & 12.420 & 4.630 & 20.209 & $* * *$ \\
\hline 2010 & - 2013 & 15.134 & 6.300 & 23.968 & $* * *$ \\
\hline 2010 & - 2009 & 28.173 & 19.513 & 36.834 & $* * *$ \\
\hline 2012 & - 2010 & -6.039 & -14.783 & 2.706 & \\
\hline 2012 & - 2011 & 6.381 & -1.740 & 14.502 & \\
\hline 2012 & - 2013 & 9.095 & -0.033 & 18.223 & \\
\hline 2012 & -2009 & 22.135 & 13.175 & 31.095 & $* * *$ \\
\hline 2011 & - 2010 & -12.420 & -20.209 & -4.630 & $* * *$ \\
\hline 2011 & - 2012 & -6.381 & -14.502 & 1.740 & \\
\hline 2011 & - 2013 & 2.714 & -5.503 & 10.931 & \\
\hline 2011 & - 2009 & 15.754 & 7.723 & 23.784 & $* * *$ \\
\hline 2013 & - 2010 & -15.134 & -23.968 & -6.300 & $* * *$ \\
\hline 2013 & - 2012 & -9.095 & -18.223 & 0.033 & \\
\hline 2013 & - 2011 & -2.714 & -10.931 & 5.503 & \\
\hline 2013 & - 2009 & 13.040 & 3.992 & 22.087 & $* * *$ \\
\hline 2009 & - 2010 & -28.173 & -36.834 & -19.513 & $* * *$ \\
\hline 2009 & -2012 & -22.135 & -31.095 & -13.175 & $* * *$ \\
\hline 2009 & - 2011 & -15.754 & -23.784 & -7.723 & $* * *$ \\
\hline 2009 & - 2013 & -13.040 & -22.087 & -3.992 & $* * *$ \\
\hline
\end{tabular}


Section B. Output for the linear model percent removal and total rain at the Washington Street site, Geauga County, Ohio, 2010-13.

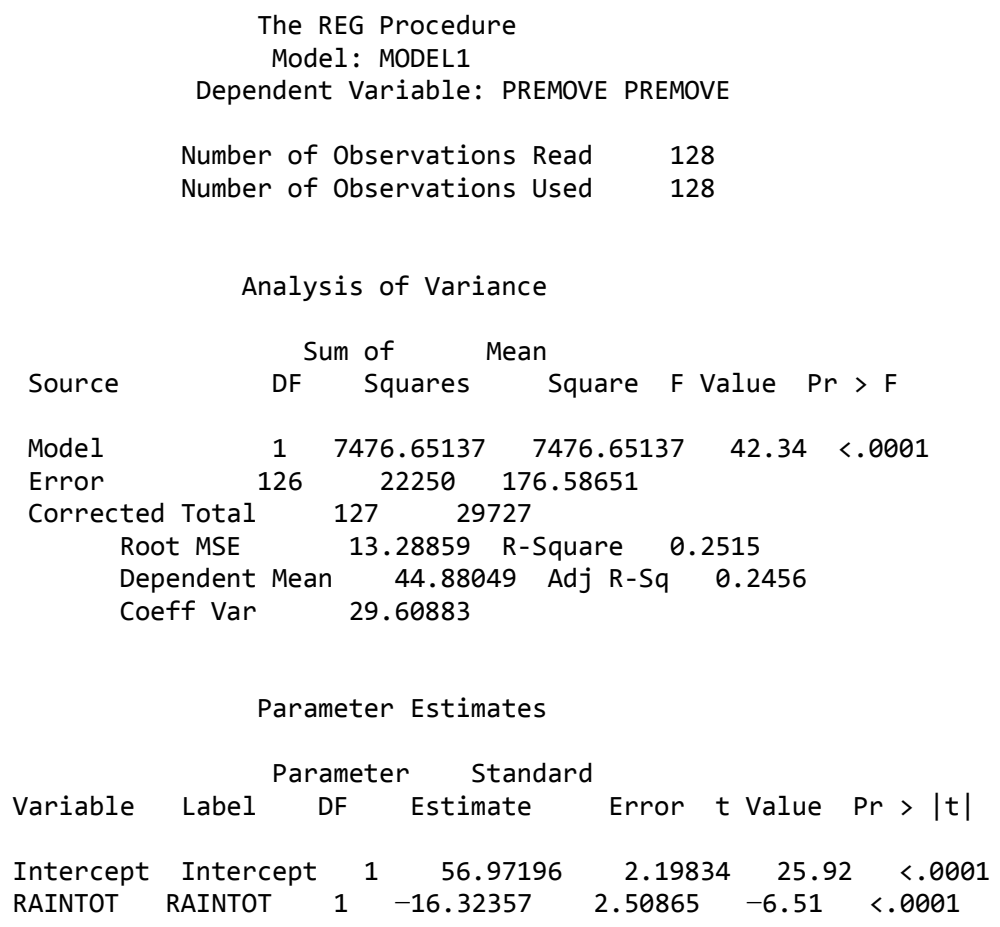


The GLM Procedure

Tukey's Studentized Range (HSD) Test for $\mathrm{R}$

NOTE: This test controls the Type I experimentwise error rate.

$\begin{array}{lc}\text { Alpha } & 0.05 \\ \text { Error Degrees of Freedom } & 124 \\ \text { Error Mean Square } & 147.1613 \\ \text { Critical Value of Studentized Range } & 3.68291\end{array}$

Comparisons significant at the 0.05 level are indicated by $* * *$.

\begin{tabular}{|c|c|c|c|c|c|}
\hline \multicolumn{6}{|c|}{ Difference } \\
\hline YEAR & & tween & Simultaneous & $95 \%$ & \\
\hline Compar & ison & Means & Confidence & Limits & \\
\hline 010 & 2012 & 5.790 & -2.526 & 14.106 & \\
\hline $2010-$ & 2011 & 12.081 & 73 & 19.489 & $* * *$ \\
\hline $2010-$ & - 2013 & 14.709 & 6.307 & 23.110 & $* * *$ \\
\hline 2012- & -2010 & -5.790 & -14.106 & 2.526 & \\
\hline $2012-$ & - 2011 & 6.290 & -1.433 & 14.014 & \\
\hline $2012-$ & - 2013 & 8.918 & 0.238 & 17.599 & $* * *$ \\
\hline 2011- & 2010 & -12.081 & -19.489 & -4.673 & $* * *$ \\
\hline 2011- & - 2012 & -6.290 & -14.014 & 1.433 & \\
\hline 2011- & - 2013 & 2.628 & -5.187 & 10.442 & \\
\hline 2013- & -2010 & -14.709 & -23.110 & -6.307 & $* * *$ \\
\hline 2013- & - 2012 & -8.918 & -17.599 & -0.238 & $* * *$ \\
\hline 2013- & - 2011 & -2.628 & -10.442 & 5.187 & \\
\hline
\end{tabular}


Section C. Output for the linear model percent removal and LOG_PN at the Washington Street site, Geauga County, Ohio, 2010-13.

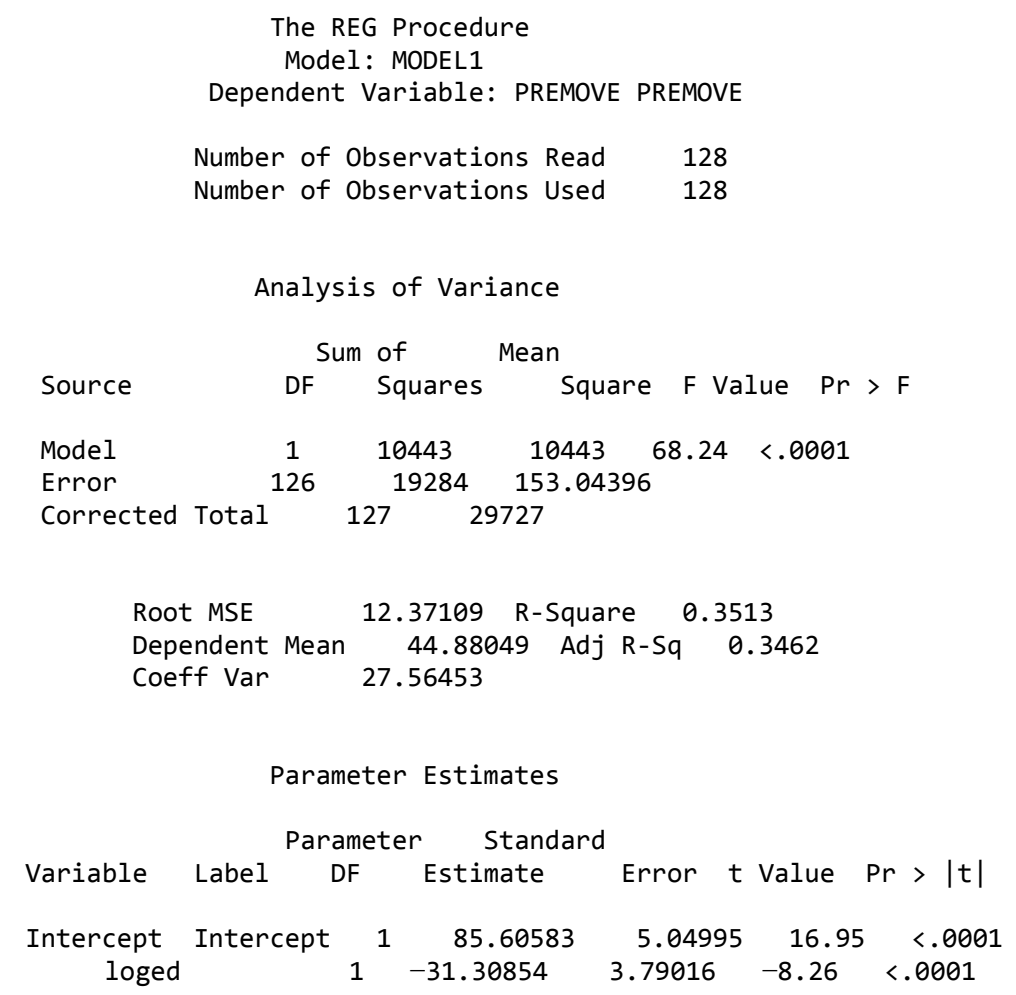


The GLM Procedure

Tukey's Studentized Range (HSD) Test for $\mathrm{R}$

NOTE: This test controls the Type I experimentwise error rate.

Alpha $\quad 0.05$

Error Degrees of Freedom 124

Error Mean Square 140.212

Critical Value of Studentized Range 3.68291

Comparisons significant at the 0.05 level are indicated by $* * *$.

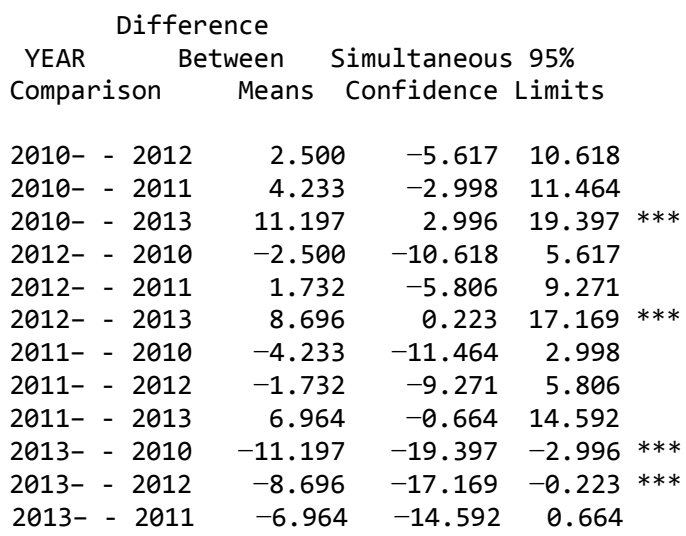


Publication services provided by the U.S. Geological Survey Science Publishing Network

Columbus Publishing Service Center

For more information concerning the research in this report contact the

Director, Ohio Water Science Center

U.S. Geological Survey

6480 Doubletree Ave

Columbus, $\mathrm{OH}$ 43229-1111

http://oh.water.usgs.gov/ 

